\title{
A systematic review of integrated working between care homes and health care services
}

\author{
Sue L Davies ${ }^{1}$, Claire Goodman ${ }^{*}$, Frances Bunn ${ }^{1}$, Christina Victor ${ }^{2}$, Angela Dickinson', Steve lliffe ${ }^{3}$, Heather Gage ${ }^{4}$ \\ Wendy Martin ${ }^{2}$ and Katherine Froggatt ${ }^{5}$
}

\begin{abstract}
Background: In the UK there are almost three times as many beds in care homes as in National Health Service (NHS) hospitals. Care homes rely on primary health care for access to medical care and specialist services. Repeated policy documents and government reviews register concern about how health care works with independent providers, and the need to increase the equity, continuity and quality of medical care for care homes. Despite multiple initiatives, it is not known if some approaches to service delivery are more effective in promoting integrated working between the NHS and care homes. This study aims to evaluate the different integrated approaches to health care services supporting older people in care homes, and identify barriers and facilitators to integrated working.

Methods: A systematic review was conducted using Medline (PubMed), CINAHL, BNI, EMBASE, Psyclnfo, DH Data, Kings Fund, Web of Science (WoS incl. SCl, SSCl, HCl) and the Cochrane Library incl. DARE. Studies were included if they evaluated the effectiveness of integrated working between primary health care professionals and care homes, or identified barriers and facilitators to integrated working. Studies were quality assessed; data was extracted on health, service use, cost and process related outcomes. A modified narrative synthesis approach was used to compare and contrast integration using the principles of framework analysis.

Results: Seventeen studies were included; 10 quantitative studies, two process evaluations, one mixed methods study and four qualitative. The majority were carried out in nursing homes. They were characterised by heterogeneity of topic, interventions, methodology and outcomes. Most quantitative studies reported limited effects of the intervention; there was insufficient information to evaluate cost. Facilitators to integrated working included care home managers' support and protected time for staff training. Studies with the potential for integrated working were longer in duration.
\end{abstract}

Conclusions: Despite evidence about what inhibits and facilitates integrated working there was limited evidence about what the outcomes of different approaches to integrated care between health service and care homes might be. The majority of studies only achieved integrated working at the patient level of care and the focus on health service defined problems and outcome measures did not incorporate the priorities of residents or acknowledge the skills of care home staff. There is a need for more research to understand how integrated working is achieved and to test the effect of different approaches on cost, staff satisfaction and resident outcomes.

\section{Background}

In the UK care homes are the major provider of long term and intermediate care for older people [1-3]. There are 18, 255 care homes providing 459, 448 beds, almost three times as many as the 167,000 hospital beds available [4]. Although people living in care homes have

\footnotetext{
* Correspondence: c.goodman@herts.ac.uk

${ }^{1}$ Centre for Research in Primary and Community Care, University of Hertfordshire, Hatfield, AL10 9AB, UK

Full list of author information is available at the end of the article
}

complex needs and represent the oldest and most frail of the older population in the UK, research consistently demonstrates that they have erratic access to NHS services, particularly those that offer specialist expertise in areas such as dementia and end of life care [5-9].

Inappropriate and unplanned hospital admissions, recognition of unmet health needs, concerns about supporting patient dignity, end of life care and access to health services have triggered multiple care home specific policy initiatives and interventions [10,11]. A

\section{Ciomed Central}


consultation event that involved care home and health care representatives identified multiple examples of the NHS working with care homes to improve information exchange, palliative care, reduce falls, and unplanned admissions to hospital [12]. These interventions often involve the introduction of specialist health workers and teams or problem specific workers to achieve the desired outcomes [13,14].

Primary health care services in England spend significant amounts of time providing care for older people resident in these settings $[15,16,7,8]$ (Goodman, $C$ et al: Can clinical benchmarking improve bowel care in care homes for older people? Final report submitted to the DoH Nursing Quality Research Initiative PRP, Centre for Research in Primary and Community Care, University of Hertfordshire, 2007). However, relatively little is known about how health care services work with the (largely unqualified) workforce to provide care to a population that has complex physical and medication needs, experiences high level of cognitive impairment, depression and is in the last few years of life $[17,18]$. The involvement of health care services in care home settings is often defined by what care home staff are not allowed to do rather than a clear understanding of how the two sectors complement each other, or work together [19]. In addition, it cannot be assumed that health service definitions of problems and services reflect how older people and care home staff define health needs and the types of health care they would like (Evans, C: The analysis of experiences and representations of older people's health in care homes to develop primary care nursing practice, unpublished PhD King's College London, 2008).

Initiatives that support continuity and integration of care for older people with complex needs across health and social care with public and private providers are increasingly recognised as important for continuity and quality of care $[20,21]$. Integration of service provision can be defined as 'a single system of needs assessment, commissioning and/or service provision that aims to promote alignment and collaboration between the cure and care sectors [22]. There are different levels of integration between health care services [23]. In the context of integrated working with care homes, these can be summarised as:

\section{Patient/Micro level}

Close collaboration between different health care professionals and care home staff e.g for the benefit of individual patients.

\section{Organisational/Meso level}

Organisational or clinical structures and processes designed to enable teams and/or organisations to work collaboratively towards common goals (e.g. integrated health and social care teams).

\section{Strategic/Macro level}

Integration of structures and processes that link organisations and support shared strategic planning and development for example, when health care services jointly fund initiatives in care homes $[24,25]$.

To understand the evidence for the benefits of different approaches to health care services supporting older people in care homes, we conducted a systematic review to identify studies using integrated working between primary health care professionals and care homes for older people; evaluated their impact on the health and well being of older people in care homes, and identified barriers and facilitators to integrated working.

\section{Methods}

The review was conducted according to inclusion criteria and methods pre-specified in a protocol developed by the authors before the review began.

\section{Inclusion criteria}

We included interventions designed to develop, promote or facilitate integrated working between care home or nursing home staff and health care practitioners. Interventions that involved staff going in to provide education or training to care home/nursing home staff were included as long as there was some description of joint working or collaboration. We excluded studies where staff were employed specifically for the purpose of the research without consideration of how the findings might be integrated into ongoing practice (i.e. project staff introduced for a limited time to deliver a specific intervention). For a study to be included there had to be evidence of at least one of the following:

Clear evidence of joint working

Joint goals or care planning

Joint arrangements covering operational and strategic issues

Shared or single management arrangements

Joint commissioning at macro and micro levels

Studies also had to report at least one of the following outcomes:

Health and well being of older people (e.g. changes in health status, quality of life)

Service use (e.g. number of GP visits, hospital admissions)

Cost such as savings due to avoided hospitalisations

Process related outcomes (such as changes in quality of care, increased staff knowledge, uptake of training and education and professional satisfaction)

As the literature in this area is limited we included all studies that involved an element of evaluation. This 
included controlled and uncontrolled studies. However, because they are more susceptible to bias, studies without a control were used to describe and catalogue interventions rather than evaluate effectiveness. Process evaluations and qualitative studies including those using action research methodologies were included in order to identify facilitators and barriers to integrated working.

\section{Identification of studies}

The electronic search strategy was conducted in February 2009. We searched the following electronic databases: Medline (PubMed), CINAHL, BNI, EMBASE, PsycInfo, DH Data, Kings Fund, Web of Science (WoS incl. SCI, SSCI, HCI) and the Cochrane Library incl. DARE. In addition, we contacted care home related interest groups and used lateral search techniques, such as checking reference lists of relevant papers, and using the 'Cited by' option on WoS, Google Scholar and Scopus, and the 'Related articles' option on PubMed and WoS. We applied no restrictions by date or country but included English language papers only. Details of the search terms used can be seen in Table 1 .

\section{Data extraction and synthesis}

Electronic search results were downloaded into EndNote bibliographic software. Two reviewers independently
(SD, FB) screened all titles and abstracts of citations identified by the electronic search, applied the selection criteria to potentially relevant papers, and extracted data from included studies using a standardised form. Any disagreements concerning studies to be included were resolved by consensus or by discussion with a third reviewer (CG).

Due to substantial heterogeneity in study design, interventions, participants and outcomes we did not pool studies in a meta-analysis. Instead a narrative summary of findings is presented and where possible we have reported dichotomous outcomes as relative risks (RR) and continuous data as mean differences (MD) (with $95 \%$ confidence intervals). Data in the evidence tables is presented with an indication of whether the intervention had a positive effect $(+)$, a negative effect $(-)$, or no statistically significant effect (0). The qualitative studies were used to generate a list of potential barriers and facilitators to integrated working. Each paper was systematically read by two researchers $(\mathrm{SD}, \mathrm{CV})$ to highlight any factors that may have impacted on the process, both those that were explicitly referred to by the authors and those identified by the reviewers within the papers' narratives.

The quality of the included studies was assessed using design assessment checklists informed by the Cochrane

Table 1 Search terms on PubMed (search terms were suitably adapted for other databases)

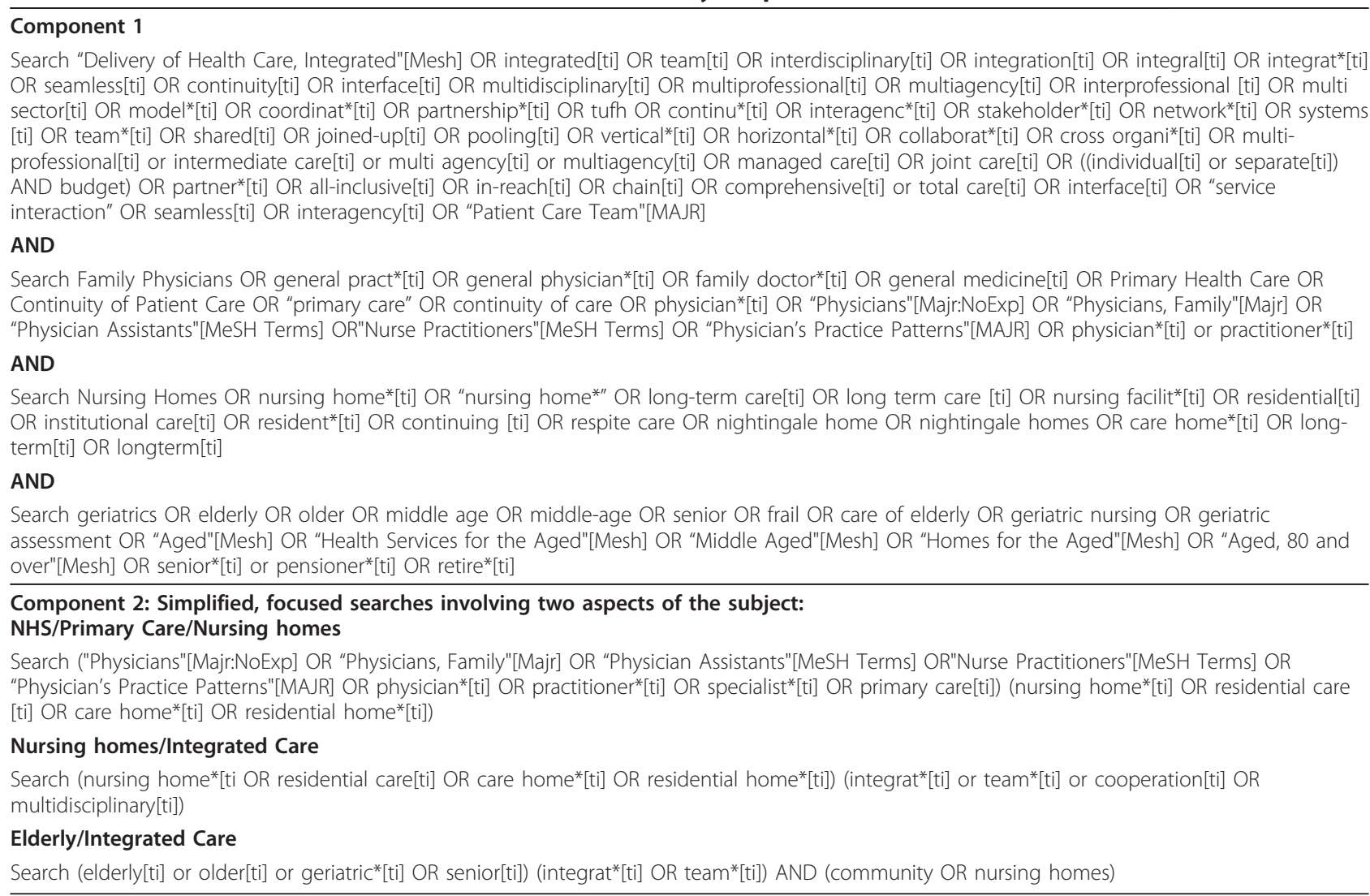


Collaboration risk of bias tool [26] and Spencer et al's quality assessment checklist for qualitative studies [27]. The core quality-assessment domains are summarised in Table 2. As other non controlled studies were used to inform contextual understanding rather than evaluate effectiveness they were not formally quality assessed.

Data were extracted from each study on methodology, type of intervention, outcomes, participants, and location. In addition, an interpretive approach based on Kodner and Spreeuwenberg's (2002) work on integrated working, was used to compare and contrast the nature and level of integration across the studies using the principles of framework analysis [28]. Each study was categorised in terms of the degree of integration and the complexity classified as micro, meso and or macro. In addition, based on the assumption that care homes with a higher level of integration would show evidence of correspondingly greater levels of support and contact with health care professionals, each study was analysed to identify the amount of contact, support and training given by the health professionals involved in the study.

\section{Results}

Figure 1 shows the flow of studies through the selection process. Seventeen studies (reported in 18 papers) met our inclusion criteria.

\section{Description of studies}

Ten studies were quantitative, (four of which were RCTs), one used mixed methods, two were process evaluations, three were qualitative and one was action research (see Table 3).

Nine were conducted in the UK, five in Australia, two in the USA and one in Sweden. Eleven (65\%) studies were conducted in nursing homes, five in residential homes and one in a combination of both. Study participants included residents, relatives, care home staff both residential and nursing, and health professionals including general practitioners, district nurses, nurse specialists, pharmacists, psychiatrists and psychologists.

Seven studies were focused on individual care, for example, specific health care needs such as end of life [29-33] or wound care [34] and dementia [35]. Six studies focused on residents' needs as a group, such as detection and treatment of depression [36], bowel related problems (Goodman, C. et al: Can clinical benchmarking improve bowel care in care homes for older people? Final report submitted to the DoH Nursing Quality Research Initiative PRP, Centre for Research in Primary and Community Care, University of Hertfordshire, 2007.) and or supporting the care home staff interactions with residents through training [37] and improved prescribing [38-40]. A further four papers were service evaluations such as an in-reach

\section{Table 2 Quality assessment criteria by study type}

\begin{tabular}{|c|c|}
\hline \multicolumn{2}{|c|}{ Randomised controlled trials all scored as Yes/No/Unclear } \\
\hline Sequence generation & Was the allocation sequence adequately generated? \\
\hline Allocation concealment & Was allocation adequately concealed? \\
\hline Blinding & Was knowledge of the allocation intervention adequately concealed from outcome assessors? \\
\hline $\begin{array}{l}\text { Incomplete outcome } \\
\text { data- }\end{array}$ & Was this adequately addressed for each outcome? \\
\hline $\begin{array}{l}\text { Selective outcome } \\
\text { reporting }\end{array}$ & Are reports of the study free of suggestion of selective outcome reporting? \\
\hline \multicolumn{2}{|c|}{ Controlled studies (without randomisation) all scored as Yes/No/Unclear } \\
\hline Baseline results reported & Were baseline results reported for each group? \\
\hline $\begin{array}{l}\text { Groups balanced at } \\
\text { baseline }\end{array}$ & Were there any significant differences in the groups at baseline? \\
\hline Blinding & Was knowledge of the allocation intervention adequately concealed from outcome assessors? \\
\hline $\begin{array}{l}\text { Incomplete outcome } \\
\text { data- }\end{array}$ & Was this adequately addressed for each outcome? \\
\hline $\begin{array}{l}\text { Selective outcome } \\
\text { reporting }\end{array}$ & Are reports of the study free of suggestion of selective outcome reporting? \\
\hline \multicolumn{2}{|c|}{ Qualitative studies - Scored as fully or mostly, partly or not at all } \\
\hline Scope and purpose & e.g. clearly stated question, clear outline of theoretical framework \\
\hline Design & e.g. discussion of why particular approach/methods chosen \\
\hline Sample & e.g. adequate description of sample used and how sample identified and recruited \\
\hline Data collection & e.g. systematic documentation of tools/guides/researcher role, recording methods explicit \\
\hline Analysis & e.g. documentation of analytic tools/methods used, evidence of rigorous/systematic analysis \\
\hline Reliability and validity & $\begin{array}{l}\text { e.g. presentation of original data, how categories/concepts/themes developed and were they checked by more than one } \\
\text { author, interpretation, how theories developed }\end{array}$ \\
\hline Generalisability & e.g. sufficient evidence for generalisability or limits made clear by author \\
\hline Credibility/plausibility & e.g. provides evidence that resonates with other knowledge, results/conclusions supported by evidence \\
\hline
\end{tabular}




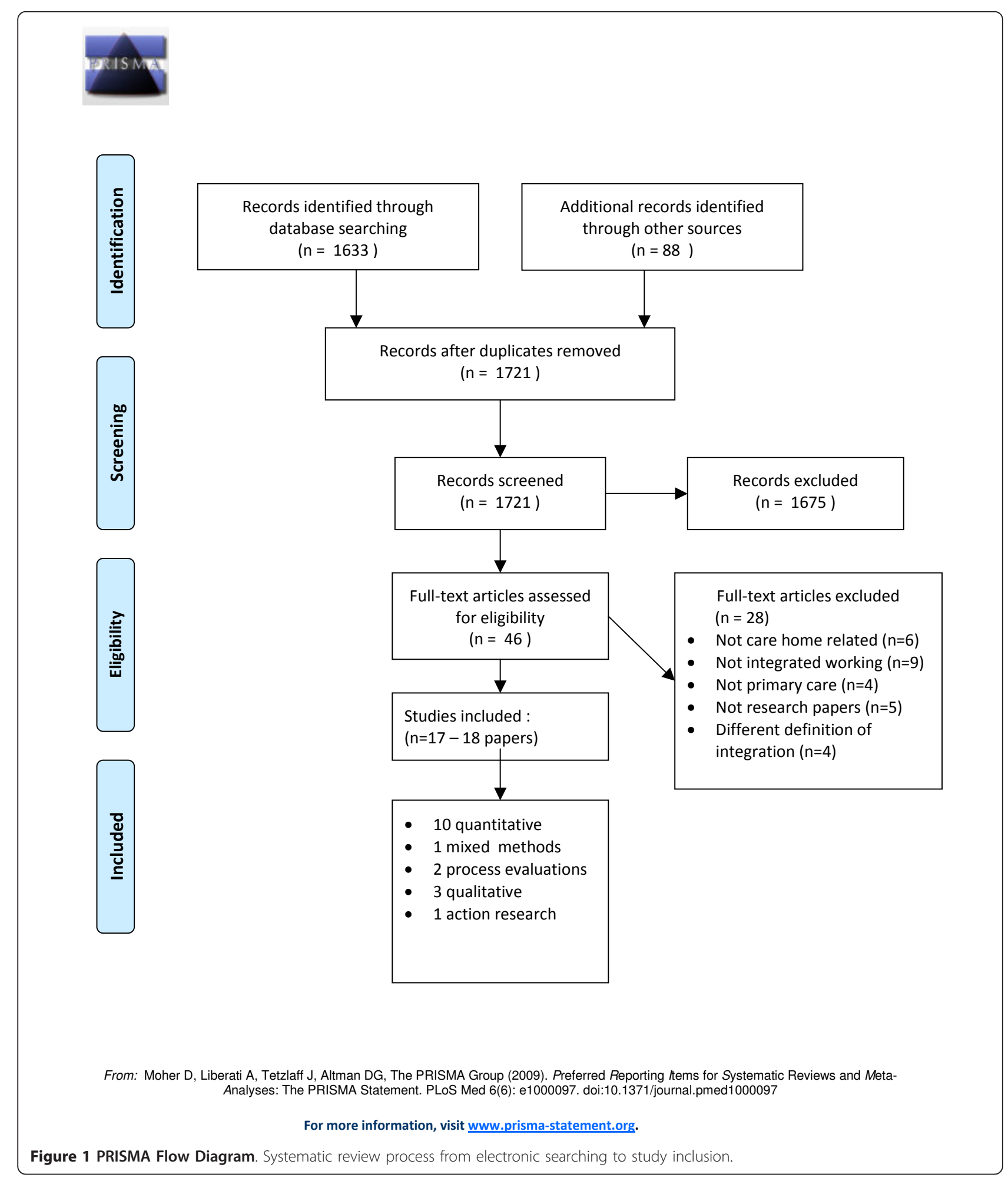

team for care homes [41], a care home support team [42], and nurse practitioners $[43,44]$. End of life care accounted for five papers [29-33], three of which focused on care pathways [30-32].

\section{Risk of bias}

There were seven controlled studies of which four were RCTs. Although the RCTs could be expected to be less susceptible to bias than the non randomised studies the 
Table 3 Studies included in the systematic review of integrated working between care homes and health care services:

\begin{tabular}{|c|c|c|c|c|c|c|}
\hline $\begin{array}{l}\text { First Author, Year } \\
\text { Title } \\
\text { Study design }\end{array}$ & $\begin{array}{l}\text { Research Question/aims } \\
\text { and objectives }\end{array}$ & $\begin{array}{l}\text { Study } \\
\text { population, } \\
\text { setting and } \\
\text { country of } \\
\text { study }\end{array}$ & $\begin{array}{l}\text { Sample size/number of } \\
\text { participants: } \\
\text { Include power calculation } \\
\text { if available }\end{array}$ & $\begin{array}{l}\text { Description of } \\
\text { intervention/ } \\
\text { Study design }\end{array}$ & $\begin{array}{l}\text { Main outcome variable(s)/ } \\
\text { Areas of focus for } \\
\text { qualitative studies }\end{array}$ & $\begin{array}{l}\text { Main findings/ } \\
\text { Conclusions }\end{array}$ \\
\hline $\begin{array}{l}\text { 1. King, } 2001 \\
\text { Multidisciplinary } \\
\text { case conference } \\
\text { reviews: improving } \\
\text { outcomes for } \\
\text { nursing home } \\
\text { residents, carers } \\
\text { and health } \\
\text { professionals } \\
\text { Controlled study }\end{array}$ & $\begin{array}{l}\text { To determine whether } \\
\text { multidisciplinary case } \\
\text { conference reviews } \\
\text { improved outcomes for } \\
\text { nursing home residents and } \\
\text { its impact on care staff. }\end{array}$ & $\begin{array}{l}\text { Population: } \\
\text { Older people in } \\
\text { nursing homes } \\
\text { Setting: } \\
3 \text { nursing homes } \\
\text { Country: } \\
\text { Australia }\end{array}$ & $\begin{array}{l}245 \text { older people } \\
\text { But only } 75 \text { residents were } \\
\text { reviewed }\end{array}$ & $\begin{array}{l}\text { Weekly case conference } \\
\text { reviews, one review per } \\
\text { resident, over } 8 \text { months } \\
\text { attended by GPs, clinical } \\
\text { pharmacist, senior nursing } \\
\text { staff and other health } \\
\text { professionals. Multidisciplinary } \\
\text { discussion of all aspects of a } \\
\text { resident's care to make } \\
\text { recommendations and devise } \\
\text { a management plan for the } \\
\text { resident. Reviews were led by } \\
\text { GPs with data collection by } \\
\text { the pharmacist. } \\
\text { Baseline and endpoint } \\
\text { comparisons were made } \\
\text { between residents who were } \\
\text { reviewed and those who } \\
\text { were not. }\end{array}$ & $\begin{array}{l}\text { Resident outcomes included: } \\
\text { medication use, administered } \\
\text { medications and weekly cost, } \\
\text { health status and quality of } \\
\text { life. } \\
\text { Carer outcomes were based } \\
\text { on resident interaction, } \\
\text { workload or personal/ } \\
\text { professional satisfaction. }\end{array}$ & $\begin{array}{l}\text { - There were no significant } \\
\text { reductions in medications } \\
\text { orders, cost and mortality. } \\
40 \% \text { of the recommendations } \\
\text { benefited residents, } \\
\text { measured through their } \\
\text { health status and quality of } \\
\text { life. } 26 \% \text { of the } \\
\text { recommendations benefited } \\
\text { care staff, but no details were } \\
\text { given. } \\
\text { Multidisciplinary case } \\
\text { conferences were seen as } \\
\text { beneficial to patients and } \\
\text { carers. Their future use was } \\
\text { recommended. }\end{array}$ \\
\hline $\begin{array}{l}\text { 2. Llewellyn-Jones, } \\
1999 \\
\text { Multifaceted shared } \\
\text { care intervention } \\
\text { for late life } \\
\text { depression in } \\
\text { residential care: } \\
\text { randomised } \\
\text { controlled trial. } \\
R C T\end{array}$ & $\begin{array}{l}\text { To evaluate the effectiveness } \\
\text { of a population based } \\
\text { multifaceted shared care } \\
\text { intervention for late life } \\
\text { depression in residential } \\
\text { care. }\end{array}$ & $\begin{array}{l}\text { Population: } \\
\text { Older people } 65 \\
\text { years + with } \\
\text { depression and } \\
\text { no or low } \\
\text { cognitive } \\
\text { impairment } \\
\text { Setting: } \\
\text { Residential facility } \\
\text { living in self care } \\
\text { units and hostels } \\
\text { not nursing } \\
\text { homes } \\
\text { (equivalent to } \\
\text { residential care in } \\
\text { UK) } \\
\text { Residents were } \\
\text { stratified and } \\
\text { randomised to } \\
\text { intervention or } \\
\text { control } \\
\text { Country: } \\
\text { Australia }\end{array}$ & $\begin{array}{l}220 \text { older people } \\
\text { No power calculation }\end{array}$ & $\begin{array}{l}\text { The shared care intervention } \\
\text { included: } \\
\text { 1. Multidisciplinary } \\
\text { consultation and } \\
\text { collaboration } \\
\text { 2. Training of gps and carers } \\
\text { in detection and } \\
\text { management of depression } \\
\text { 3. Depression related health } \\
\text { education and activity } \\
\text { programmes for residents. } \\
\text { The control group received } \\
\text { routine care. }\end{array}$ & Geriatric Depression Scale & $\begin{array}{l}\text { There was a significant } \\
\text { reduction in adjusted } \\
\text { depression scores for } \\
\text { residents in the intervention } \\
\text { group. } \\
\text { Multidisciplinary } \\
\text { collaboration, staff education, } \\
\text { health education and activity } \\
\text { programmes can improve } \\
\text { depression in older people in } \\
\text { residential care. }\end{array}$ \\
\hline
\end{tabular}


Table 3 Studies included in the systematic review of integrated working between care homes and health care services: (Continued)

\begin{tabular}{|c|c|c|c|c|c|c|}
\hline $\begin{array}{l}\text { 3. Opie, } 2002 \\
\text { Challenging } \\
\text { behaviours in } \\
\text { nursing home } \\
\text { residents with } \\
\text { dementia: a } \\
\text { randomised } \\
\text { controlled trial of } \\
\text { multidisciplinary } \\
\text { interventions. } \\
\text { RCT }\end{array}$ & $\begin{array}{l}\text { To test whether individually } \\
\text { tailored psychosocial, } \\
\text { nursing and medical } \\
\text { interventions to nursing } \\
\text { home residents with } \\
\text { dementia will reduce the } \\
\text { frequency and severity of } \\
\text { behavioural symptoms. }\end{array}$ & $\begin{array}{l}\text { Population; } \\
\text { Nursing home } \\
\text { residents with } \\
\text { severe dementia } \\
\text { rated by staff as } \\
\text { having frequent, } \\
\text { severe } \\
\text { behavioural } \\
\text { disturbances. } \\
\text { Setting: } 42 \\
\text { Nursing homes } \\
\text { Country: } \\
\text { Australia }\end{array}$ & $\begin{array}{l}102 \text { older people } \\
\text { entered the } \\
\text { study, ( } 99 \text { completed the } 4 \\
\text { week trial, } 2 \text { RIPs } 1 \\
\text { hospitalisation) }\end{array}$ & $\begin{array}{l}\text { Residents selected on basis } \\
\text { of CMAl scores and assigned } \\
\text { to early or late intervention } \\
\text { groups. } \\
\text { Consultancy team with } \\
\text { training in psychiatry, } \\
\text { psychology and nursing met } \\
\text { weekly for } 30 \text { minutes, to } \\
\text { discuss referrals and } \\
\text { formulate individualised care } \\
\text { plans which were presented } \\
\text { to nursing home staff to } \\
\text { implement. Plans were } \\
\text { reviewed at one week. } 3 \\
\text { categories: medical, based on } \\
\text { medication review, nursing, } \\
\text { based on ADLs, and } \\
\text { psychosocial including } \\
\text { environment, sensory } \\
\text { stimulation. The control was } \\
\text { normal care, residents acted } \\
\text { as their own controls by } \\
\text { being in the early or late } \\
\text { intervention groups. }\end{array}$ & $\begin{array}{l}\text { Frequency and severity of } \\
\text { disruptive behaviours and } \\
\text { assessment of change by } \\
\text { senior nursing staff. } \\
\text { Tools included: } \\
\text { Cohen-Mansfield Agitation } \\
\text { Inventory (CMAl) which } \\
\text { assesses frequency of } 30 \\
\text { behaviours over previous } 14 \\
\text { days } \\
\text { Behaviour Assessment } \\
\text { Graphical System (BAGS) } \\
\text { which records a combined } \\
\text { frequency and disruption } \\
\text { score every hour for } 24 \\
\text { hours. }\end{array}$ & $\begin{array}{l}\text { There was a slight reduction } \\
\text { in the daily observed counts } \\
\text { of challenging behaviours. } \\
\text { Individualised, } \\
\text { multidisciplinary interventions } \\
\text { appear to reduce the } \\
\text { frequency and severity of } \\
\text { challenging behaviours in } \\
\text { nursing homes }\end{array}$ \\
\hline $\begin{array}{l}\text { 4. Schmidt, } 1998 \\
\text { The Impact of } \\
\text { Regular } \\
\text { Multidisciplinary } \\
\text { Team Interventions } \\
\text { on Psychotropic } \\
\text { Prescribing in } \\
\text { Swedish Nursing } \\
\text { Homes } \\
\text { RCT }\end{array}$ & $\begin{array}{l}\text { To evaluate the impact of } \\
\text { regular multidisciplinary } \\
\text { team interventions on the } \\
\text { quantity and quality of } \\
\text { psychotropic drug } \\
\text { prescribing in nursing } \\
\text { homes } \\
\text { Aim was to improve } \\
\text { prescribing through better } \\
\text { teamwork amongst } \\
\text { physicians, pharmacists, } \\
\text { nurses and nursing assistants }\end{array}$ & $\begin{array}{l}\text { Population: } \\
\text { Long term } \\
\text { residents, 42\% } \\
\text { dementia, 5\% } \\
\text { psychotic } \\
\text { disorder, } 7 \% \\
\text { depression } \\
\text { Setting: } 33 \\
\text { Nursing homes } \\
\text { Country: } \\
\text { Sweden }\end{array}$ & $\begin{array}{l}1854 \text { residents } \\
\text { In } 15 \text { experimental homes } \\
\text { and } 18 \text { control homes }\end{array}$ & $\begin{array}{l}\text { Regular multidisciplinary } \\
\text { team meetings over } 12 \\
\text { months to discuss individual } \\
\text { residents drug use. } \\
\text { Training was provided for } \\
\text { pharmacists but not for other } \\
\text { staff. } \\
\text { Control homes provided } \\
\text { normal care. }\end{array}$ & $\begin{array}{l}\text { Baseline and } 12 \text { month post } \\
\text { resident medications }\end{array}$ & $\begin{array}{l}\text { After } 12 \text { months the } \\
\text { intervention group showed } \\
\text { an improvement in the } \\
\text { prescribing of hypnotics only. } \\
\text { Prescribing practices can be } \\
\text { improved through better } \\
\text { teamwork between health } \\
\text { care and nursing home staff } \\
\text { using clinical guidelines. }\end{array}$ \\
\hline
\end{tabular}


Table 3 Studies included in the systematic review of integrated working between care homes and health care services: (Continued)

\begin{tabular}{|c|c|c|c|c|c|c|}
\hline $\begin{array}{l}\text { 5. Vu, } 2007 \\
\text { Cost-effectiveness } \\
\text { of multidisciplinary } \\
\text { wound care in } \\
\text { nursing homes: a } \\
\text { pseudo-randomized } \\
\text { pragmatic cluster } \\
\text { trial } \\
\text { Pseudo RCT }\end{array}$ & $\begin{array}{l}\text { Trial to test the hypothesis } \\
\text { that trained pharmacists and } \\
\text { nurses working in } \\
\text { collaboration with a wound } \\
\text { treatment protocol would } \\
\text { improve the wound healing } \\
\text { and save costs. }\end{array}$ & $\begin{array}{l}\text { Population: } \\
176 \text { residents } \\
\text { with leg or } \\
\text { pressure wounds } \\
\text { Setting: } \\
44 \text { high care } \\
\text { nursing homes } \\
\text { Country: } \\
\text { Australia }\end{array}$ & $\begin{array}{l}\text { Based on an assumed } \\
\text { improvement in the healing } \\
\text { rate from } 15 \% \text { to } 30 \%, 108 \\
\text { wounds per arm were } \\
\text { required to have an } 80 \% \\
\text { chance of detecting a two- } \\
\text { fold increase in healing rates } \\
\text { at a significance level of 5\%. } \\
\text { To adjust for clustering this } \\
\text { number was increased to } 151 \\
\text { in each group. }\end{array}$ & $\begin{array}{l}\text { Residents in the intervention } \\
\text { arm received standardised } \\
\text { treatment from a wound care } \\
\text { team comprised of trained } \\
\text { community pharmacists and } \\
\text { nurses. A standard treatment } \\
\text { protocol was developed } \\
\text { based on the colour, depth } \\
\text { and exudate method for } \\
\text { assessing wounds and the } \\
\text { group's clinical and academic } \\
\text { experience. They met weekly } \\
\text { to discuss any new wounds } \\
\text { and treatment options within } \\
\text { the protocol. Both nurses and } \\
\text { pharmacists received training } \\
\text { on wound healing and } \\
\text { management. }\end{array}$ & $\begin{array}{l}\text { Treatment recommendations, } \\
\text { frequency and detail of } \\
\text { dressing changes, } \\
\text { measurement and photos of } \\
\text { wounds, SF36, Assessment of } \\
\text { Quality of Life index, Brief } \\
\text { Pain Inventory - measures } \\
\text { wound pain, total estimated } \\
\text { cost of treatment per wound } \\
\text { including, staff time, training, } \\
\text { wound care products and } \\
\text { waste disposal. }\end{array}$ & $\begin{array}{l}\text { During the trial more } \\
\text { wounds healed in the } \\
\text { intervention than in the } \\
\text { control group but this was } \\
\text { not significant. The mean } \\
\text { treatment cost of wound } \\
\text { healing was significantly less } \\
\text { in the intervention group. } \\
\text { Standardised treatment by a } \\
\text { multidisciplinary wound care } \\
\text { team cut costs and improved } \\
\text { chronic wound healing in } \\
\text { nursing homes. }\end{array}$ \\
\hline $\begin{array}{l}\text { 6. Crotty } 2004 \\
\text { An outreach } \\
\text { geriatric medication } \\
\text { advisory service in } \\
\text { residential aged } \\
\text { care: a randomised } \\
\text { controlled trial of } \\
\text { case conferencing. } \\
\text { Cluster } R C T\end{array}$ & $\begin{array}{l}\text { Evaluate the impact of } \\
\text { multidisciplinary case } \\
\text { conferences on the } \\
\text { appropriateness of } \\
\text { medications and on patient } \\
\text { behaviours in residential } \\
\text { care }\end{array}$ & $\begin{array}{l}\text { Population: } \\
\text { residents with } \\
\text { medication } \\
\text { problems/ } \\
\text { challenging } \\
\text { behaviours } \\
\text { Setting: } 10 \text { High- } \\
\text { level aged care } \\
\text { facilities } \\
\text { Country: } \\
\text { Australia }\end{array}$ & $\begin{array}{l}154 \text { residents recruited with } \\
54 \text { in control, } 50 \text { in } \\
\text { intervention, } 50 \text { in within } \\
\text { facility control group } \\
5 \text { facilities randomised to the } \\
\text { intervention and } 5 \text { to the } \\
\text { control } \\
\text { Staff nominated } 20 \text { residents } \\
\text { for the intervention and } 10 \\
\text { for the control, based on } 2 \\
\text { criteria: } \\
\text { Residents with a difficult } \\
\text { behaviour they would like } \\
\text { advice on, those prescribed } 5 \\
\text { + medications } \\
\text { An effect size based on } \\
\text { patients aged } 65+\text { with } \\
\text { polypharmacy of } 0.9 \text { in the } \\
\text { MAl between the } \\
\text { intervention and control } \\
\text { groups (power } 0.9 \text {, type } 1 \\
\text { error of } 0.05 \text { ) would be } \\
\text { detected with } 28 \text { residents in } \\
\text { each group }\end{array}$ & $\begin{array}{l}2 \text { multidisciplinary case } \\
\text { conferences chaired by the } \\
\text { resident's GP, a geriatrician, } \\
\text { pharmacist and residential } \\
\text { care staff held at the nursing } \\
\text { home for each resident. } \\
\text { All facilities received a half } \\
\text { day workshop on using the } \\
\text { toolkit for challenging } \\
\text { behaviour } \\
\text { All residents had their } \\
\text { medication chart reviewed } \\
\text { pre and post intervention by } \\
\text { an independent pharmacist } \\
\text { using the MAl }\end{array}$ & $\begin{array}{l}\text { Assessed at baseline and } 3 \\
\text { months } \\
\text { Primary outcome the } \\
\text { Medication Appropriateness } \\
\text { Index (MAl) } \\
\text { Nursing Home Behaviour } \\
\text { Problem Scale for each } \\
\text { resident }\end{array}$ & $\begin{array}{l}\text { There was a significant } \\
\text { improvement in appropriate } \\
\text { medication in the } \\
\text { intervention group compared } \\
\text { with the control group. } \\
\text { Resident behaviours were } \\
\text { unchanged after the } \\
\text { intervention. }\end{array}$ \\
\hline
\end{tabular}


Table 3 Studies included in the systematic review of integrated working between care homes and health care services: (Continued)

\begin{tabular}{|c|c|c|c|c|c|c|}
\hline $\begin{array}{l}\text { 7. Joseph } 1998 \\
\text { Managed Primary } \\
\text { Care of Nursing } \\
\text { Home Residents } \\
\text { Cohort study }\end{array}$ & $\begin{array}{l}\text { To measure the rates of } \\
\text { hospital use and mortality of } \\
\text { nursing home residents who } \\
\text { received their primary care } \\
\text { from practitioner-physician } \\
\text { teams. }\end{array}$ & $\begin{array}{l}\text { Population: } \\
\text { older long term } \\
\text { residents of } \\
\text { nursing homes } \\
\text { enrolled in } \\
\text { Medicare HMO } \\
\text { Setting: } \\
30 \text { nursing } \\
\text { homes in } \\
\text { Southern } \\
\text { California } \\
\text { Country: USA }\end{array}$ & 307 nursing home residents & $\begin{array}{l}\text { Primary care by accessible } \\
\text { interdisciplinary team } \\
\text { including physicians, nurse } \\
\text { practitioners, and nursing } \\
\text { home staff supported by } \\
\text { clinical guidelines, continuous } \\
\text { improvement techniques and } \\
\text { increased availability of } \\
\text { clinical services at the nursing } \\
\text { homes. }\end{array}$ & $\begin{array}{l}\text { Demographics, mortality, } \\
\text { hospital days, minimum data } \\
\text { sets }\end{array}$ & $\begin{array}{l}\text { Integrated working between } \\
\text { doctors, nurse practitioners } \\
\text { and nursing home staff can } \\
\text { reduce nursing home } \\
\text { resident's hospital use. }\end{array}$ \\
\hline $\begin{array}{l}\text { 8. Kane } 2004 \\
\text { Effect of an } \\
\text { Innovative } \\
\text { Medicare Managed } \\
\text { Care Program on } \\
\text { the Quality of Care } \\
\text { for Nursing Home } \\
\text { Residents } \\
\text { Controlled study }\end{array}$ & $\begin{array}{l}\text { To assess the quality of care } \\
\text { provided by Medicare HMO } \\
\text { targeted specifically at } \\
\text { nursing home residents, } \\
\text { employing nurse } \\
\text { practitioners to provide } \\
\text { additional primary care to } \\
\text { the physicians. }\end{array}$ & $\begin{array}{l}\text { Population: } \\
\text { Long stay } \\
\text { nursing home } \\
\text { residents } \\
\text { Setting: Nursing } \\
\text { homes } \\
\text { Country: USA }\end{array}$ & $\begin{array}{l}44 \text { Evercare homes } 44 \\
\text { control homes } \\
2 \text { control groups } \\
\text { a) other residents in same } \\
\text { homes not enrolled in } \\
\text { Evercare } \\
\text { b) residents in homes in } \\
\text { same geographical area that } \\
\text { did not participate in } \\
\text { Evercare }\end{array}$ & $\begin{array}{l}\text { Evercare model of managed } \\
\text { care using nurse practitioners } \\
\text { to provide additional primary } \\
\text { care over and above that } \\
\text { provided by physicians. }\end{array}$ & $\begin{array}{l}4 \text { aspects of quality: mortality, } \\
\text { preventable hospitalisations, } \\
\text { quality indicators, derived } \\
\text { from the Minimum Data set } \\
\text { and changes in functioning. }\end{array}$ & $\begin{array}{l}\text { The Evercare mortality rate } \\
\text { was significantly lower than } \\
\text { the control-in group but not } \\
\text { the control-out group. The } \\
\text { Evercare residents had fewer } \\
\text { preventable hospitalisation s } \\
\text { the difference was significant } \\
\text { for one of the control } \\
\text { groups. }\end{array}$ \\
\hline $\begin{array}{l}\text { 9. Goodman } \\
2007 \\
\text { Controlled study }\end{array}$ & $\begin{array}{l}\text { To assess whether clinical } \\
\text { benchmarking can be } \\
\text { incorporated into care } \\
\text { homes for older people with } \\
\text { the support of NHS primary } \\
\text { care nursing staff }\end{array}$ & $\begin{array}{l}\text { Population } \\
\text { Older people in } \\
\text { residential care } \\
\text { homes } \\
\text { Setting: } 7 \\
\text { residential care } \\
\text { homes ( } 6+1 \\
\text { pilot home) } \\
\text { Country: UK }\end{array}$ & $\begin{array}{l}46 \text { Care home staff and } 154 \\
\text { older people from } 6 \\
\text { residential care homes } \\
12 \text { district nurses from } 6 \\
\text { district nursing teams in } 3 \\
\text { PCTs. }\end{array}$ & $\begin{array}{l}3 \text { intervention care homes } \\
\text { used Essence of Care } \\
\text { benchmarking in relation to } \\
\text { resident's bowel care, joint } \\
\text { implementation for all } \\
\text { residents by care home staff } \\
\text { working together with senior } \\
\text { district nursing staff over six } \\
\text { months. Regular } \\
\text { benchmarking meetings to } \\
\text { discuss, plan and implement } \\
\text { specific aspects of bowel } \\
\text { related health promotion and } \\
\text { continence care that would } \\
\text { be suitable for residents. DN } \\
\text { led bowel care training } \\
\text { sessions for other care staff in } \\
\text { the care homes. Non- } \\
\text { intervention care homes } \\
\text { received usual care from their } \\
\text { district nursing teams }\end{array}$ & $\begin{array}{l}\text { Main outcome variables were } \\
\text { bowel related problems } \\
\text { captured in a bowel diary } \\
\text { recorded for residents pre } \\
\text { and post intervention and } \\
\text { related hospital admissions, } \\
\text { medication and continence } \\
\text { product use, time spent on } \\
\text { bowel related activities, staff } \\
\text { satisfaction and turnover. }\end{array}$ & $\begin{array}{l}\text { Clinical benchmarking could } \\
\text { be utilised in care homes as } \\
\text { part of everyday working } \\
\text { with district nurses and used } \\
\text { few resources. However, } \\
\text { commitment by both parties } \\
\text { and mutual trust was } \\
\text { necessary for the process to } \\
\text { be successful. Bowel care was } \\
\text { complex and challenging for } \\
\text { care staff especially where } \\
\text { older people were cognitively } \\
\text { impaired. There was no } \\
\text { significant reduction in bowel } \\
\text { related problems but some } \\
\text { evidence of improved } \\
\text { documentation and } \\
\text { appropriate prescribing. }\end{array}$ \\
\hline
\end{tabular}


Table 3 Studies included in the systematic review of integrated working between care homes and health care services: (Continued)

\begin{tabular}{|c|c|c|c|c|c|c|}
\hline $\begin{array}{l}\text { 10. Szczepura, } 2008 \\
\text { In-reach specialist } \\
\text { nursing teams for } \\
\text { residential care } \\
\text { homes: uptake of } \\
\text { services, impact on } \\
\text { care provision and } \\
\text { cost-effectiveness. } \\
\text { Economic evaluation }\end{array}$ & $\begin{array}{l}\text { Evaluation of a dedicated } \\
\text { nursing and physiotherapy } \\
\text { in-reach team (IRT) }\end{array}$ & $\begin{array}{l}\text { Population: } \\
\text { older people in } \\
\text { care homes } \\
\text { Setting; } 4 \\
\text { residential care } \\
\text { homes } \\
\text { Country: UK }\end{array}$ & 131 residents & $\begin{array}{l}\text { IRT gives } 24 \text { hour cover } 7 \\
\text { days a week - a specialist } \\
\text { team offers support and } \\
\text { onsite care for up to } 15 \text { beds } \\
\text { for specialist nursing care to } \\
\text { prevent transfer to hospital } \\
\text { or nursing home. It also } \\
\text { supports care home staff } \\
\text { through health training up to } \\
\text { NVQ level 3. }\end{array}$ & $\begin{array}{l}\text { Cost of the service } \\
\text { Number of referrals to the } \\
\text { service } \\
\text { Reasons for referral/visits by } \\
\text { team } \\
\text { Hospitalisations and nursing } \\
\text { home transers avoided }\end{array}$ & $\begin{array}{l}\text { IRT resulted in savings } \\
\text { through reduced } \\
\text { hospitalisations, early } \\
\text { discharges, delayed transfers } \\
\text { to nursing homes and illness } \\
\text { recognition. } \\
\text { Introduction of an in-reach } \\
\text { team was at least cost } \\
\text { neutral. It also benefited the } \\
\text { care home staff through } \\
\text { training which enhanced the } \\
\text { quality of care and reduced } \\
\text { the transfer of residents to } \\
\text { other care facilities. }\end{array}$ \\
\hline $\begin{array}{l}\text { 11. Proctor, } 1998 \\
\text { An observational } \\
\text { study to evaluate } \\
\text { the impact of a } \\
\text { specialist outreach } \\
\text { team on the quality } \\
\text { of care in nursing } \\
\text { and residential } \\
\text { homes } \\
\text { Quantitative - non- } \\
\text { participant } \\
\text { observation }\end{array}$ & $\begin{array}{l}\text { To assess the applicability of } \\
\text { a training and support } \\
\text { programme for care staff in } \\
\text { nursing and residential } \\
\text { homes on the quality of } \\
\text { staff-resident interaction }\end{array}$ & $\begin{array}{l}\text { Population: } \\
\text { Older people } \\
\text { considered by } \\
\text { staff to have } \\
\text { problems in } \\
\text { terms of } \\
\text { behaviour, social } \\
\text { functioning or } \\
\text { psychiatric } \\
\text { symptoms } \\
\text { Setting: } 5 \\
\text { residential } \\
\text { homes, } 1 \text { nursing } \\
\text { home } \\
\text { Country: UK }\end{array}$ & $\begin{array}{l}12 \text { residents - } 2 \text { from each } \\
\text { home } \\
51 \text { care home staff }\end{array}$ & $\begin{array}{l}\text { 1. Staff training over } 6 \\
\text { months included } \\
\text { Seminars provided by a } \\
\text { multidisciplinary team } \\
\text { including old age } \\
\text { psychiatrists, nurses, doctors } \\
\text { and OTs. } \\
\text { A behavioural approach to } \\
\text { care planning to help staff } \\
\text { plan and implement care } \\
\text { plans for individual residents. } \\
\text { Training was given by a } \\
\text { psychiatric nurse with weekly } \\
\text { visits to staff }\end{array}$ & $\begin{array}{l}\text { Resident behaviour and staff } \\
\text { contact was recorded } \\
\text { through non-participant } \\
\text { observation prior to the } \\
\text { training, } 3 \text { and } 6 \text { months } \\
\text { post } \\
\text { Activities recorded were } \\
\text { based on QUIS - Quality of } \\
\text { Interactions Schedule (Dean } \\
\text { et al, 1993) }\end{array}$ & $\begin{array}{l}\text { There was a significant } \\
\text { increase in the proportion of } \\
\text { time that staff spent in } \\
\text { positive interactions with } \\
\text { residents (direct care } p< \\
0.002 \text {, social contact } p<0.05 \text { ) } \\
\text { and levels of resident activity } \\
\text { increased ( } p<0.001 \text { ). }\end{array}$ \\
\hline $\begin{array}{l}\text { 12. Knight, } 2007 \\
\text { All-Wales } \\
\text { integrated care } \\
\text { pathway project for } \\
\text { care homes } \\
\text { Process evaluation/ } \\
\text { audit }\end{array}$ & $\begin{array}{l}\text { To facilitate the } \\
\text { implementation of ICP into } \\
\text { care homes through } \\
\text { negotiation with local } \\
\text { palliative care providers to } \\
\text { improve the care for dying } \\
\text { patients }\end{array}$ & $\begin{array}{l}\text { Population: } \\
\text { Older people in } \\
\text { nursing homes } \\
\text { Setting: } \\
29 \text { nursing } \\
\text { homes in Wales } \\
\text { Country: UK }\end{array}$ & $\begin{array}{l}130 \text { older people pre- } \\
\text { intervention, } 133 \text { post } \\
\text { intervention }\end{array}$ & $\begin{array}{l}\text { Introduction of an integrated } \\
\text { care pathway for dying } \\
\text { patients in care homes. Other } \\
\text { support: } \\
\text { - Education subgroup } \\
\text { - ICP education pack } \\
\text { - Teaching sessions } \\
\text { - Syringe driver training } \\
\text { - Matron forums } \\
\text { - Informal training/support }\end{array}$ & $\begin{array}{l}\text { Pre and post ICP audit of } \\
\text { dying patient's notes to } \\
\text { measure their quality. Pre- } \\
\text { audit highlighted poor } \\
\text { communication, symptom } \\
\text { control, and lack of staff end } \\
\text { of life care education. }\end{array}$ & $\begin{array}{l}\text { The re-audit indicated an } \\
\text { improvement in recording } \\
\text { end of life care. ICP use in } \\
\text { the care homes had } \\
\text { increased from } 3 \text { to } 31 \% \text { in } \\
\text { one year. Recording of events } \\
\text { and documentation } \\
\text { remained poor. }\end{array}$ \\
\hline $\begin{array}{l}\text { 13. Mathews, } 2006 \\
\text { Using the Liverpool } \\
\text { Care Pathway in a } \\
\text { nursing home } \\
\text { Process evaluation/ } \\
\text { Audit }\end{array}$ & $\begin{array}{l}\text { Aim to illustrate how } \\
\text { collaborative working in a } \\
\text { nursing home using the } \\
\text { Liverpool Care Pathway(LCP) } \\
\text { can enhance end of life } \\
\text { patient care and improve } \\
\text { palliative care education }\end{array}$ & $\begin{array}{l}\text { Population: } \\
\text { Older people } \\
\text { resident in a } \\
\text { nursing home } \\
\text { Setting: } 1 \\
\text { nursing home } \\
\text { Country: UK }\end{array}$ & $\begin{array}{l}150 \text { residents with } 50 \text { bed } \\
\text { contracted out to the NHS } \\
\text { for end of life care }\end{array}$ & $\begin{array}{l}\text { Pilot study to introduce LCP } \\
\text { into a nursing home. LCP } \\
\text { discussed with GPS, } \\
\text { pharmacist and ambulance } \\
\text { service. } \\
\text { Trained nursing staff received } \\
3 \text { hours of palliative care } \\
\text { training including using LCP. } \\
\text { Followed by implementation } \\
\text { of the LCP for patients. }\end{array}$ & $\begin{array}{l}\text { Focus on improving } \\
\text { documentation and } \\
\text { symptom control of patients }\end{array}$ & $\begin{array}{l}\text { An audit of the first } 10 \\
\text { patients on the LCP showed } \\
\text { an improvement in } \\
\text { documentation and } \\
\text { assessment of symptoms. } \\
\text { Staff felt that the training } \\
\text { should be extended to } \\
\text { health care assistants. A } \\
\text { steering group was also set } \\
\text { up to discuss the pathway } \\
\text { and training needs. }\end{array}$ \\
\hline
\end{tabular}


Table 3 Studies included in the systematic review of integrated working between care homes and health care services: (Continued)

\begin{tabular}{|c|c|c|c|c|c|c|}
\hline $\begin{array}{l}\text { 14. Doherty, } 2008 \\
\text { Examining the } \\
\text { impact of a } \\
\text { specialist care } \\
\text { homes support } \\
\text { team } \\
\text { Qualitative }\end{array}$ & $\begin{array}{l}\text { To examine the work the } \\
\text { work and perceived impact } \\
\text { of a dedicated care homes } \\
\text { support team } \\
\text { Aim of the care homes } \\
\text { support team was to enable } \\
\text { staff to manage the health } \\
\text { and social care needs of } \\
\text { residents to avoid } \\
\text { unnecessary admission to } \\
\text { hospital }\end{array}$ & $\begin{array}{l}\text { Population: } \\
\text { Older people in } \\
\text { care homes } \\
\text { Setting: } \\
29 \text { Care homes? } \\
\text { residential } \\
\text { Country: UK }\end{array}$ & $\begin{array}{l}19 \text { care home managers, } 13 \\
\text { CHST including specialist } \\
\text { older peoples nurse, } \\
\text { pharmacist, GP, and Senior } \\
\text { managers in PCT interviewed } \\
32+\text { participants interviewed }\end{array}$ & $\begin{array}{l}\text { Intensive component:: } 5 \text { care } \\
\text { homes CHST promoted } \\
\text { practice development } \\
\text { through action plans } \\
\text { focusing on staff identified } \\
\text { needs } \\
\text { Extensive component: } 29 \\
\text { homes where CHST acted as } \\
\text { a resource in terms of } \\
\text { information sharing and } \\
\text { networking but no } \\
\text { development working }\end{array}$ & $\begin{array}{l}\text { Processes, working methods } \\
\text { and outcomes of the care } \\
\text { home support team }\end{array}$ & $\begin{array}{l}\text { Statistical analysis did not } \\
\text { support the effectiveness of } \\
\text { the care homes support } \\
\text { team, but the qualitative data } \\
\text { showed the impact of the } \\
\text { team through empowering } \\
\text { staff, increased quality of life } \\
\text { and access to services for } \\
\text { residents and professional } \\
\text { development for staff. }\end{array}$ \\
\hline $\begin{array}{l}\text { 15. Hasson, } 2008 \\
\text { The palliative care } \\
\text { link nurse role in } \\
\text { nursing homes: } \\
\text { barriers and } \\
\text { facilitators } \\
\text { Qualitative }\end{array}$ & $\begin{array}{l}\text { To explore link nurses' views } \\
\text { and experiences regarding } \\
\text { the development, barriers } \\
\text { and facilitators to the } \\
\text { implementation of the role } \\
\text { in palliative care in the } \\
\text { nursing home }\end{array}$ & $\begin{array}{l}\text { Population: } \\
\text { Older people in } \\
\text { nursing homes } \\
\text { Setting: } 33 \\
\text { nursing homes } \\
\text { Country: UK }\end{array}$ & $\begin{array}{l}33 \text { nursing homes } \\
14 \text { link nurses in } 3 \text { focus } \\
\text { groups }\end{array}$ & $\begin{array}{l}\text { Link nurse initiative - } 3 \\
\text { phases over } 3 \text { years: } \\
\text { 1. Training needs or nurses } \\
\text { and nursing assistants } \\
\text { assessed } \\
\text { 2. Palliative care educational } \\
\text { programme for staff and } \\
\text { identification of link nurses } \\
\text { identified in nursing homes } \\
\text { 3. Evaluation of link nurses by } \\
\text { nursing home staff }\end{array}$ & $\begin{array}{l}\text { Topics in focus groups } \\
\text { included; link nurse } \\
\text { preparation, barriers and } \\
\text { facilitators to delivery of } \\
\text { education in the home }\end{array}$ & $\begin{array}{l}\text { The link nurse system had } \\
\text { the potential to improve } \\
\text { palliative care in nursing } \\
\text { homes. Facilitators included } \\
\text { external and peer support, } \\
\text { monthly meetings and access } \\
\text { to information. Barriers } \\
\text { included the transient } \\
\text { workforce and a lack of } \\
\text { preparation for the role. }\end{array}$ \\
\hline $\begin{array}{l}\text { 16. Avis } 1999 \\
\text { Evaluation of a } \\
\text { project providing } \\
\text { community } \\
\text { palliative care } \\
\text { support to nursing } \\
\text { homes } \\
\text { Qualitative }\end{array}$ & $\begin{array}{l}\text { Evaluation of project to } \\
\text { extend 'hospice standards' } \\
\text { of palliative care to nursing } \\
\text { homes }\end{array}$ & $\begin{array}{l}\text { Population: } \\
231 \text { Nursing } \\
\text { home residents } \\
\text { Setting: Nursing } \\
\text { homes with } \\
\text { registered } \\
\text { palliative care } \\
\text { beds } \\
\text { Country: UK }\end{array}$ & $\begin{array}{l}2 \text { Questionnaire surveys of } 39 \\
\& 43 \text { matrons of nursing } \\
\text { homes, at } 6 \text { months and at } \\
\text { the end of the project } \\
35 \text { Interviews with local } \\
\text { stakeholders }\end{array}$ & $\begin{array}{l}\text { Project was implemented by } \\
\text { a nurse advisor and a peer } \\
\text { support group of } 6 \text { district } \\
\text { nurses who delivered the } \\
\text { service to nursing homes. } \\
\text { Nursing home staff made } \\
\text { referrals to the team who } \\
\text { responded by visiting and } \\
\text { assisting in assessments and } \\
\text { care plans for residents. } \\
1^{\text {st }} \text { phase involved } \\
\text { assessment of services } \\
\text { required by nursing homes } \\
\text { identified by matrons. Focus } \\
\text { on } 3 \text { areas: advice on } \\
\text { individual care problems, } \\
\text { training and support on } \\
\text { palliative care, pain, symptom } \\
\text { control, accessing specialist } \\
\text { advice and offering support } \\
\text { to relatives and residents } \\
\text { including bereavement } \\
\text { counselling. }\end{array}$ & $\begin{array}{l}\text { Interviews explored } \\
\text { participant's understanding of } \\
\text { the project, their perceptions } \\
\text { of issued involved in } \\
\text { providing palliative care, } \\
\text { benefits, limitations for staff } \\
\text { and residents. } \\
\text { Questionnaires were used to } \\
\text { rate project performance, } \\
\text { access, response time, liaison, } \\
\text { benefits and limitations of } \\
\text { the project. Services were } \\
\text { also rated in order of their } \\
\text { importance for care homes } \\
\text { and residents. }\end{array}$ & $\begin{array}{l}\text { The project helped to } \\
\text { overcome the barriers to care } \\
\text { between NHS services and } \\
\text { the independent sector. Care } \\
\text { home isolation was } \\
\text { decreased through assistance } \\
\text { with individual care and } \\
\text { better access to specialist } \\
\text { advice and training. }\end{array}$ \\
\hline
\end{tabular}


Table 3 Studies included in the systematic review of integrated working between care homes and health care services: (Continued)

\begin{tabular}{|c|c|c|c|c|c|}
\hline $\begin{array}{l}\text { 17. Hockley } 2005 \\
\text { (primary) } \\
\text { Promoting end of } \\
\text { life care in nursing } \\
\text { homes using an } \\
\text { integrated care } \\
\text { pathway for the } \\
\text { last days of life } \\
\text { 18. Watson } 2006 \\
\text { (secondary) } \\
\text { Barriers to } \\
\text { implementing an } \\
\text { integrated care } \\
\text { pathway for the } \\
\text { last days of life in } \\
\text { nursing homes } \\
\text { Action research }\end{array}$ & $\begin{array}{l}\text { To promote quality end of } \\
\text { life care in nursing homes } \\
\text { using an integrated care } \\
\text { pathway document. } \\
\text { Explores the barriers that } \\
\text { needed to be overcome } \\
\text { during the implementation } \\
\text { of an integrated care } \\
\text { pathway for eol care }\end{array}$ & $\begin{array}{l}\text { Population: } \\
\text { Older people in } \\
\text { nursing homes } \\
\text { Setting: } 8 \\
\text { independent } \\
\text { nursing homes } \\
\text { Country: UK }\end{array}$ & $\begin{array}{l}\text { Use of action research to } \\
\text { promote collaboration } \\
\text { between staff in nursing } \\
\text { homes and the research } \\
\text { team, empower staff in } \\
\text { practice of eol care and } \\
\text { promote sustainable eol care } \\
\text { once study complete. } \\
\text { - Core research team of } 3 \\
\text { nurses with palliative care } \\
\text { and action research } \\
\text { experience, }+2 \text { champions } \\
\text { were identified in each care } \\
\text { home } \\
\text { Facilitation to implement ICP: } \\
\text { - Monthly action learning sets } \\
\text { for champions, monthly } \\
\text { collaborative learning groups } \\
\text { for all staff to reflect on eol } \\
\text { care and ICP documents of } \\
\text { residents who had died, } \\
\text { clinical support from nurse } \\
\text { specialist researcher. }\end{array}$ & $\begin{array}{l}\text { Interviews to explore the } \\
\text { respondents' understanding } \\
\text { of the project, their } \\
\text { perceptions of the issues in } \\
\text { providing palliative nursing } \\
\text { care and the benefits and } \\
\text { limitations of the project for } \\
\text { staff and residents } \\
\text { Questionnaires focussed on: } \\
\text { their use of the project, } \\
\text { access, response time and } \\
\text { liaison, perceptions of the } \\
\text { benefits and limitations and } \\
\text { the difficulties experienced in } \\
\text { providing palliative. } \\
\text { Data was also collected } \\
\text { through field notes, action } \\
\text { learning sets, monthly } \\
\text { collaborative learning groups. }\end{array}$ & $\begin{array}{l}\text { Dying became more central } \\
\text { to nursing home work. Five } \\
\text { main themes emerged, a } \\
\text { greater openness to death, } \\
\text { recognition of dying, better } \\
\text { teamwork, using palliative } \\
\text { care knowledge to influence } \\
\text { practice and better } \\
\text { communication. }\end{array}$ \\
\hline
\end{tabular}


potential for bias in both groups of studies appeared to be high (see Tables 4 and 5 ).

A number of the studies appeared underpowered and for many follow up was short. The qualitative studies employed a range of methodologies including action research, interviews, focus groups and questionnaires. As with the quantitative studies, the quality was low, only two out of four $[30,33]$ had a clearly defined purpose and design. With one exception [33] descriptions of the study sample, data collection and analysis were inadequate and evidence of their credibility and transferability was limited (see Table 6).

\section{Effectiveness}

The heterogeneity of outcomes and, in particular, the interventions meant that making comparisons between studies was problematic. Three studies looked at the effect on prescribing [38-40], three included mortality as an outcome $[39,40,44]$ and two looked at disruptive behaviour [35,39]. The remaining outcomes, only included in single studies, were depression [36], hospital admissions [40], functional status [40], wound healing [34], and bowel related problems (Goodman, $C$ et al: Can clinical benchmarking improve bowel care in care homes for older people? Final report submitted to the DoH Nursing Quality Research Initiative PRP, Centre for Research in Primary and Community Care, University of Hertfordshire, 2007). Full details of the results can be seen in Table 7. Although there were some improvements in outcomes, the majority of studies showed that the intervention had either mixed effects (that is improvement in one outcome but no effect or negative effect in another outcome), or no effect when compared with the control group. Insufficient information was available to evaluate the cost of integrated working between care homes and primary health care professionals.

\section{The nature of integrated working}

There was a great deal of variation in how health care services and care homes worked together and the frequency of contact. For example, whilst some studies involved weekly multidisciplinary team meetings [43], monthly meetings were more common (Goodman, $\mathrm{C}$ et al: Can clinical benchmarking improve bowel care in care homes for older people? Final report submitted to the DoH Nursing Quality Research Initiative PRP, Centre for Research in Primary and Community Care, University of Hertfordshire, 2007)[30]. All the studies potentially increased care home staff access to health care professional's support and advice, with 15 out of 17 involving care home staff in multidisciplinary interventions or joint working. Care home staff were involved in multidisciplinary meetings and in some studies their opinions were sought [40], but they were led by health care professionals, with health care orientated and defined goals. Staff training was an integral part of all studies bar three; only a few studies consulted with care home staff on their perceived training needs $[29,33]$. The range of training input varied from as little as three hours [31] to seven seminars [37] or continuous training and support $[43,44]$.

The level of integration for all studies and the degree of support and training provided by NHS staff for care home is reported in Table 8. The majority of studies showed micro integration at the clinical level involving close collaboration between care home staff and health care professionals to achieve specific outcomes (12 out of the 17) e.g. wound care techniques and wound healing. The remaining five studies were integrated at the clinical level but also showed greater complexity of integration in terms of funding and organisation or strategy, one at the meso level [42] and four at the macro level $[31,41,43,44]$. In service delivery, four studies used dedicated multidisciplinary teams to support staff and residents in care homes [42], three of which achieved their remit of avoiding unnecessary hospitalisation $[41,43,44]$. Two UK studies also had health service funded beds within care homes, one for use by a specialist health care nursing team [41] the other to provide end of life care [31]. A distinguishing feature of four out of the five studies classified at higher levels of integration was that care home staff received support and or training which was ongoing, as opposed to being offered at discrete time periods during the intervention. For example, nursing home staff were facilitated to recognise and manage acute conditions [43], to improve residents' overall care [44].

Table 4 RCTs Quality assessment results

\begin{tabular}{llllll}
\hline Study & $\begin{array}{l}\text { Sequence generation } \\
\text { adequate? }\end{array}$ & $\begin{array}{l}\text { Allocation concealment } \\
\text { adequate }\end{array}$ & $\begin{array}{l}\text { Blinding of outcome } \\
\text { assessment }\end{array}$ & $\begin{array}{l}\text { Incomplete outcome } \\
\text { data assessed? }\end{array}$ & $\begin{array}{l}\text { Free from selective } \\
\text { reporting? }\end{array}$ \\
\hline Crotty 2004 & $Y$ & $Y$ & $N$ & $Y$ & $Y$ \\
\hline $\begin{array}{l}\text { Llewellyn- } \\
\text { Jones 1999 }\end{array}$ & $Y$ & $U$ & $Y$ & $N$ & $Y$ \\
\hline Opie 2002 & Y & Y & $Y$ & $Y$ \\
\hline Schmidt 1998 & $U$ & $U$ & $N$ & $U$ & $Y$ \\
\hline
\end{tabular}


Table 5 Non randomised controlled studies quality assessment results

\begin{tabular}{llllll}
\hline Study & $\begin{array}{l}\text { Baseline results } \\
\text { reported? }\end{array}$ & $\begin{array}{l}\text { Groups balanced at } \\
\text { baseline? }\end{array}$ & $\begin{array}{l}\text { Blinding of outcome } \\
\text { assessment }\end{array}$ & $\begin{array}{l}\text { Incomplete outcome data } \\
\text { assessed? }\end{array}$ & $\begin{array}{l}\text { Free from selective } \\
\text { reporting? }\end{array}$ \\
\hline $\begin{array}{l}\text { Goodman } \\
\text { 2007 }\end{array}$ & Y & Y & $N$ & N \\
\hline King 2001 & Y & N & N & $Y$ & $Y$ \\
\hline Kane 2004 & N & N & Y & N & $Y$ \\
\hline Vu 2007 & Y & N & N & $Y$ & $Y$ \\
\hline
\end{tabular}

A number of cross cutting themes that influenced the achievement of integrated working were identified (See Tables 9 and 10). These included, care home access to services and the different working cultures of care home staff and health care professionals that acted as barriers and facilitators. Care home staff identified a lack of support from health care professionals and a failure to recognise their knowledge and skills $[29,33,42]$. There were negative perceptions on both sides with care home staff feeling that health care professionals were sometimes acting in a 'policing' rather than an advisory capacity $[29,42]$ and health care professionals perceiving care home staff as lacking in knowledge and expertise, and unwilling to change their practice [30].

Whilst input and training from health care staff was valued, for care home staff to access it, dedicated time and finance from care home managers was necessary. Holding sessions within the care home and setting up a learning contract with the staff could facilitate training [32]. Examples of positive interactions included one care home support team described as acting as a link to the outside world' by the care home, and supporting clinical decision making across the multi disciplinary team [42]. Difficulty in maintaining levels of staff skills and knowledge were exacerbated by the high staff turnover experienced by care homes $[29,32,33]$. However, one study found a higher rate of staff turnover amongst the health care professionals involved in the intervention than the senior staff in the care homes (Goodman, C et al: Can clinical benchmarking improve bowel care in care homes for older people? Final report submitted to the DoH Nursing Quality Research Initiative PRP, Centre for Research in Primary and Community Care, University of Hertfordshire, 2007). Consistency of care home managers was identified as an important factor in building collaborative working with health care professionals [32].

\section{Discussion}

We found 17 studies, eight of which were controlled evaluations. Although some of the studies reported positive outcomes most interventions had mixed or no effects when compared with the control group. There was insufficient information available to evaluate the cost of integrated working between care homes and primary health care professionals. Some of the qualitative studies suggested that integrated working had the potential to improve the quality of life for older people in care homes through increased support for care home staff and increased access to health care services. A small number of studies which were integrated at the macro or meso level, involved care homes that were supported by dedicated health service teams and health service funded beds or managed care, showed more positive outcomes such as avoidance of hospitalisation. They also differed from the micro integrated studies in their capacity to give ongoing support and training for care home staff, which had the potential to address one of the main identified barriers to integrated working and ultimately improve resident's care. This indicates that

Table 6 Quality review scores for qualitative papers.

\begin{tabular}{|c|c|c|c|c|c|c|c|c|c|}
\hline Study & $\begin{array}{l}\text { Scopel } \\
\text { purpose }\end{array}$ & Design & Sample & $\begin{array}{l}\text { Data } \\
\text { collection }\end{array}$ & Analysis & $\begin{array}{l}\text { Reliability/ } \\
\text { validity }\end{array}$ & $\begin{array}{l}\text { Generalisability/ } \\
\text { transferability }\end{array}$ & $\begin{array}{l}\text { Credibility/integrity/ } \\
\text { plausibility }\end{array}$ & $\begin{array}{l}\text { Ethics } \\
\text { approval }\end{array}$ \\
\hline Avis 1999 & $\sim$ & - & - & - & - & - & - & $\sim$ & - \\
\hline $\begin{array}{l}\text { Doherty } \\
2008\end{array}$ & $\sim$ & + & $\sim$ & - & $\sim$ & - & - & + & + \\
\hline $\begin{array}{l}\text { Hasson } \\
2008\end{array}$ & + & + & + & + & + & + & $\sim$ & + & + \\
\hline $\begin{array}{l}\text { Hockley } \\
2005\end{array}$ & + & + & $\sim$ & $\sim$ & - & $\sim$ & $\sim$ & + & + \\
\hline
\end{tabular}

Scoring key:

+ Fully or mostly scores 1

- Not at all

$\sim$ Partly scores 0 . 
Table 7 Results from RCTs and controlled studies

\begin{tabular}{ll}
\hline Study ID & Outcome \\
\hline $\begin{array}{ll}\text { Crotty } 2004 & \begin{array}{l}\text { Appropriate prescribing (medication appropriateness } \\
\text { index }\end{array}\end{array}$
\end{tabular}

Main results at follow up

$(+)=$ positive effect, $(-)=$ negative effect, $(0)=$ no significant effect

Follow up at 3 months (NB - two control groups - one external and one within the facility (results presented for external control grp only))

Change MAI score (+) Mean score (95\% Cl)Intervention 4.10 (2.116.10), Control $0.41(-0.42-1.23)$, Difference $p=0.004$

Nursing home behaviour problem

Change NHBPS (0), Mean score (95\% Cl)Intervention 3.9 (-2.7-

10.5), Control 1.2 (-9.1-11.6), $P=0.440$

Mortality

Mortality (0)

No differences between groups $(p=0.304)$

Goodman 2007 (non Bowel related problems

Follow up at 6 months

randomised controlled

Normal bowel patterns $(+)$

study)

Intervention - significant increase in normal bowel patters,

control grp - little change

Medication and continence related product use

Prescription of laxatives (0)

Increase in both groups but no statistically significant differences between groups $p=0.159$

Dependency (Barthel index)

Dependency $(+)$ Mean change score $p=0.002$ Intervention -0.02 (SD 3.1), Control -1.84 (SD 3.7)

Bowel related hospital admission 1 admission in intervention grp, none in control $(n=120)$

King 2001 (non randomised controlled study) Follow up at 1 month. Data collected on 184 residents (75 reviewed, 109 not reviewed).

Medication prescribed
Medication administered

Weekly Cost (\$) - authors say study underpowered for this outcome

Mortality (adjusted for length of time in home)
Changes in medication prescribed - mean (SD) (0) Intervention -0.35 (2.56), Control -0.03 (1.90) P = 0.37

Changes in medication administered - mean (SD) (0) Intervention -0.44 (2.45), Control $0.12(1.84), P=0.16$

Weekly cost (0)

Intervention -0.29 (10.80), Control 0.43 (12.16), P = 0.75

Mortality (0)

Adjusted mortality data showed $6 \%$ of reviewed residents died compared to $15 \%$ of those not reviewed $p=0.07$

Kane 2004 (controlled study) - evaluating

EverCare

Follow up at 18 months

2 control groups

a) other residents in same homes not enrolled in Evercare

b) residents in homes in same geographical area that did not participate $n$ Evercare

Assessments at 6,12, 18 months (within 30 days)

Mortality

Mortality

Evercare rate significantly less than for control-in group but was slightly higher than control-out group (non significant)

Preventable hospitalizations

Rates of preventable admissions lower in Evercare than for either control but only significant when compared to control-out.

No differences in hospitalization rates overall. (0)

Functional change

\begin{tabular}{ll}
\hline Llewellyn-Jones 1999 & $\begin{array}{l}\text { Geriatric depression scale (score of } \geq 10 \text { defined as } \\
\text { depressed) }\end{array}$
\end{tabular}

No significant differences in ADLs between Evercare and either control. (0)

Follow up after 9.5 months

Depression

Unadjusted MD (0)

$-0.76(-2.09,0.57)$

Adjusted difference in change score (+)

Multiple linear regression analysis

Intervention group 1.87 improvement on scale compared to control group $(95 \% \mathrm{Cl} 0.76,2.97) p=0.0011$

Opie 2002

RCT (poor study design)
Frequency \& severity of disruptive behaviours (Behaviour Assessment Graphical System and counts of certain behaviours)
Follow up at one month

Frequency of disruptive behaviour (0)

ANOVA revealed no statistically significant changes

BAGS scores (0)

No significant between group differences 
Table 7 Results from RCTs and controlled studies (Continued)

\begin{tabular}{|c|c|c|}
\hline & $\begin{array}{l}\text { Assessment of change by senior nursing home staff - } \\
\text { rated on } 4 \text { point scale(interviewed one month after } \\
\text { completion of trial) }\end{array}$ & $\begin{array}{l}\text { Assessment by staff } \\
\text { No data reported on between group differences. } \\
\text { Staff reported that the frequency of target behaviours had } \\
\text { decreased in at least one behavioural category for } 75 \% \text { residents } \\
\text { and that severity had decreased in at least one category for } 60 \% \text {. }\end{array}$ \\
\hline $\begin{array}{l}\text { Schmidt } 1998 \\
\text { RCT }\end{array}$ & $\begin{array}{l}\text { Proportion of pts with any psychotropic drug (from lists } \\
\text { of residents prescriptions) }\end{array}$ & $\begin{array}{l}\text { Follow up at } 12 \text { months } \\
\text { Any psychotropic drug use (0) } \\
\text { RR } 0.97(95 \% \text { Cl 0.92, 1.03) }\end{array}$ \\
\hline \multirow[t]{5}{*}{ Involves pharmacists } & $\begin{array}{l}\text { Proportion of residents with two or more drug classes } \\
\text { (polymedicine) }\end{array}$ & $\begin{array}{l}\text { Two or more drug classes }(0) \\
\text { RR } 1.02(0.92,1.13)\end{array}$ \\
\hline & $\begin{array}{l}\text { Proportion of residents with therapeutic duplication } \\
\text { (two or more drugs in same class) }\end{array}$ & $\begin{array}{l}\text { Two or more drugs in same class } \\
\text { RR } 0.92(0.76,1.10)\end{array}$ \\
\hline & Number of drugs prescribed & $\begin{array}{l}\text { Number of drugs prescribed (mean) } \\
2.08 \% \text { versus } 2.20 \% \\
\text { Significant increase in average number of drugs prescribed in } \\
\text { control before to after. } \\
\text { No change in experimental homes. }\end{array}$ \\
\hline & $\begin{array}{l}\text { Proportion of residents with non recommended drugs } \\
\text { (as defined by Swedish guidelines) }\end{array}$ & $\begin{array}{l}\text { Non recommended hypnotics }(+) \\
\text { RR } 0.45(0.35,0.58) \\
\text { Non recommended anxiolytics }(0) \\
\text { RR } 0.96(0.79,1.16) \\
\text { Non recommended antidepressant }(0) \\
\text { RR } 0.67(0.44,1.03) \\
\text { Acceptable hypnotics }(+) \\
\text { RR } 1.46(1.13,1.89)\end{array}$ \\
\hline & $\begin{array}{l}\text { Proportion of residents with acceptable drugs (as } \\
\text { defined by Swedish guidelines) }\end{array}$ & $\begin{array}{l}\text { Acceptable anxiolytics }(0) \\
\text { RR } 1.19(0.97,1.45) \\
\text { Acceptable antidepressant (-) } \\
\text { RR } 1.34(1.07,1.68)\end{array}$ \\
\hline Vu 2007 (Pseudo RCT) & Percentage healed & $\begin{array}{l}\text { Follow up at } 20 \text { weeks } \\
\text { Healed }(0) \text { - but baseline wound severity greater in intervention } \\
\text { group } \\
\text { Intervention } 61.7 \% \text {, control } 52.5 \% \mathrm{p}=0.074\end{array}$ \\
\hline \multirow[t]{3}{*}{ Involves pharmacists } & Mean time to healing & $\begin{array}{l}\text { Time to healing (mean days) (0) } \\
\text { Intervention } 82.0 \text { (69.1-94.9), Control } 101.1 \text { (84.5-117.6), } \mathrm{P}=0.095\end{array}$ \\
\hline & Total pain relief (Brief pain inventory) & $\begin{array}{l}\text { Pain relief - BPI score }=0(+) \\
\text { Intervention } 38.6 \% \text {, control } 24.4 \% p=0.017\end{array}$ \\
\hline & Costs & $\begin{array}{l}\text { Mean treatment costs }(+) \\
\text { Reduction in mean treatment costs of } 357.7 \text { Australian dollars } \\
\text { when training costs included } p=0.004\end{array}$ \\
\hline
\end{tabular}

for integrated working to be successful, formal structures may need to be in place for health service delivery and organisation of care for care homes.

Despite the lack of evidence on effectiveness, studies consistently demonstrated key issues that supported or militated against integrated working. These findings are significant for future research and the development of interventions that rely on integrated working between health care services and care home staff. Barriers to integrated working included a failure to acknowledge the expertise of care home staff, their lack of access to health care services, as well as high care home staff turnover and limited availability of training. Facilitators to integrated working were the care home manager's support for the intervention, protected time and the inclusion of all levels of care home staff for training and support by health care professionals.
A common feature of the interventions was the use of multidisciplinary teams to improve one or more aspect of older people's health care. However, all the studies were led and conducted by health care professionals. There was no evidence of care home staff being involved in the definition or focus of the studies and some evidence that care home staff felt that their knowledge and views were not valued. Seven studies employed external project staff in some capacity, which implies that integrated working may require some external facilitation.

Three studies used integrated care pathways as a means of improving the quality of end of life care for older people resident in care homes. Care pathways may increase integrated working for the individual older people who have them, but this will not necessarily extend to the care home residents as a whole. The use of a shared assessment and care framework and 
Table 8 Level of integration, care home staff support and training

\begin{tabular}{|c|c|c|c|c|c|c|}
\hline Study & Model & $\begin{array}{l}\text { 1. Care staff } \\
\text { involved in team } \\
\text { meetings/joint } \\
\text { working }\end{array}$ & $\begin{array}{l}\text { 2. Level of care home } \\
\text { staff support }\end{array}$ & $\begin{array}{l}3 . \\
\text { Training } \\
\text { for care } \\
\text { home } \\
\text { staff }\end{array}$ & Training details & $\begin{array}{l}\text { Level and features of } \\
\text { integration }\end{array}$ \\
\hline $\begin{array}{l}\text { Llewellyn- } \\
\text { Jones, } \\
1999\end{array}$ & $\begin{array}{l}\text { Multidisciplinary } \\
\text { case conferences }\end{array}$ & $\sqrt{ }$ & $\begin{array}{l}\text { Duration of intervention } \\
\text { only - no information on } \\
\text { length }\end{array}$ & $\sqrt{ }$ & $\begin{array}{l}\text { Duration of intervention } \\
\text { only - no information on length }\end{array}$ & $\begin{array}{l}\text { Micro } \\
\text { Close collaboration } \\
\text { between health care } \\
\text { professionals and care } \\
\text { home staff }\end{array}$ \\
\hline King, 2001 & $\begin{array}{l}\text { Multidisciplinary } \\
\text { consultation \& } \\
\text { collaboration }\end{array}$ & $\begin{array}{l}\sqrt{ } \\
\text { Senior nursing } \\
\text { staff only }\end{array}$ & $\begin{array}{l}\text { Duration of intervention } \\
\text { only - } \\
8 \text { months }\end{array}$ & $x$ & $x$ & $\begin{array}{l}\text { Micro } \\
\text { Close collaboration } \\
\text { between health care } \\
\text { professionals and care } \\
\text { home staff }\end{array}$ \\
\hline Opie, 2002 & $\begin{array}{l}\text { Multidisciplinary } \\
\text { consultation \& } \\
\text { collaboration }\end{array}$ & $\times$ & $\begin{array}{l}\text { Duration of intervention } \\
\text { Only - } \\
4 \text { weeks }\end{array}$ & $\times$ & $x$ & $\begin{array}{l}\text { Micro } \\
\text { Close collaboration } \\
\text { between health care } \\
\text { professionals and care } \\
\text { home staff }\end{array}$ \\
\hline $\begin{array}{l}\text { Schmidt, } \\
1998\end{array}$ & $\begin{array}{l}\text { Multidisciplinary } \\
\text { team meetings }\end{array}$ & $\sqrt{ }$ & $\begin{array}{l}\text { Duration of intervention } \\
\text { only } 1 \text { year }\end{array}$ & $x$ & $x$ & $\begin{array}{l}\text { Micro } \\
\text { Close collaboration } \\
\text { between health care } \\
\text { professionals and care } \\
\text { home staff }\end{array}$ \\
\hline$\overline{V u, 2007}$ & $\begin{array}{l}\text { Multidisciplinary } \\
\text { consultation \& } \\
\text { collaboration }\end{array}$ & $\sqrt{ }$ & $\begin{array}{l}\text { Duration of intervention } \\
\text { only1 year }\end{array}$ & $\sqrt{ }$ & $\begin{array}{l}\text { Training wound management. } \\
\text { No details }\end{array}$ & $\begin{array}{l}\text { Micro } \\
\text { Close collaboration } \\
\text { between health care } \\
\text { professionals and care } \\
\text { home staff }\end{array}$ \\
\hline $\begin{array}{l}\text { Crotty, } \\
2004\end{array}$ & $\begin{array}{l}\text { Multidisciplinary } \\
\text { case conferences }\end{array}$ & $\sqrt{ }$ & $\begin{array}{l}\text { Duration of intervention } \\
\text { only } \\
1 \text { year }\end{array}$ & $\sqrt{ }$ & $\begin{array}{l}\text { Half day workshop on managing } \\
\text { challenging behaviours }\end{array}$ & $\begin{array}{l}\text { Micro } \\
\text { Close collaboration } \\
\text { between health care } \\
\text { professionals and care } \\
\text { home staff }\end{array}$ \\
\hline $\begin{array}{l}\text { Joseph, } \\
1998\end{array}$ & $\begin{array}{l}\text { Multidisciplinary } \\
\text { care }\end{array}$ & $\sqrt{ }$ & $\begin{array}{l}\text { Ongoing weekly } \\
\text { meetings to discuss } \\
\text { deaths, hospitalisations } \\
\text { and complications }\end{array}$ & $\sqrt{ }$ & $\begin{array}{l}6 \text { hours of seminars every year. } \\
\text { Ongoing training and feedback } \\
\text { in the management of acute } \\
\text { conditions }\end{array}$ & $\begin{array}{l}\text { Macro } \\
\text { Nurse practitioners } \\
\text { employed to provide } \\
\text { additional primary care } \\
\text { Managed care Hospital } \\
\text { avoidance }\end{array}$ \\
\hline Kane, 2004 & $\begin{array}{l}\text { Multidisciplinary } \\
\text { care }\end{array}$ & No information & $\begin{array}{l}\text { Ongoing support but no } \\
\text { details }\end{array}$ & $\sqrt{ }$ & $\begin{array}{l}\text { Ongoing no information on the } \\
\text { amount. Focus on training care } \\
\text { home staff to improve resident's } \\
\text { care }\end{array}$ & $\begin{array}{l}\text { Macro } \\
\text { Nurse practitioners } \\
\text { employed to provide } \\
\text { additional primary care } \\
\text { Managed care Hospital } \\
\text { avoidance }\end{array}$ \\
\hline $\begin{array}{l}\text { Goodman, } \\
2007\end{array}$ & $\begin{array}{l}\text { Multidisciplinary } \\
\text { consultation \& } \\
\text { collaboration }\end{array}$ & $\sqrt{ }$ & $\begin{array}{l}\text { Duration of intervention } \\
\text { only approximately } \\
\text { monthly over } \\
6 \text { months }\end{array}$ & $\sqrt{ }$ & $\begin{array}{l}\text { Duration of intervention } \\
\text { One training session for care } \\
\text { home staff in one care home }\end{array}$ & $\begin{array}{l}\text { Micro } \\
\text { Close collaboration } \\
\text { between health care } \\
\text { professionals and care } \\
\text { home staff }\end{array}$ \\
\hline $\begin{array}{l}\text { Szczepura, } \\
2008\end{array}$ & $\begin{array}{l}\text { Multidisciplinary } \\
\text { care }\end{array}$ & $\sqrt{ }$ & $\begin{array}{l}\text { Ongoing over } \\
2 \text { years }\end{array}$ & $\sqrt{ }$ & $\begin{array}{l}\text { Ongoing over } \\
2 \text { years }\end{array}$ & $\begin{array}{l}\text { Macro } \\
\text { Dedicated nursing and } \\
\text { physiotherapy In-reach } \\
\text { team } \\
\text { Dedicated care home } \\
\text { beds } \\
\text { Hospital avoidance } \\
\text { Joint NHS - local } \\
\text { authority initiative. }\end{array}$ \\
\hline
\end{tabular}


Table 8 Level of integration, care home staff support and training (Continued)

\begin{tabular}{|c|c|c|c|c|c|c|}
\hline $\begin{array}{l}\text { Proctor, } \\
1998\end{array}$ & $\begin{array}{l}\text { Multidisciplinary } \\
\text { Training - high } \\
\text { level of staff } \\
\text { involvement }\end{array}$ & $\sqrt{ }$ & $\begin{array}{l}\text { Duration of intervention } \\
6 \text { months, weekly visits } \\
\text { by specialist nurse }\end{array}$ & $\sqrt{ }$ & $\begin{array}{l}\text { Duration of intervention - } 7 \text { one } \\
\text { hour seminars by } \\
\text { multidisciplinary team on topics } \\
\text { chosen by care staff }\end{array}$ & $\begin{array}{l}\text { Micro } \\
\text { Close collaboration } \\
\text { between health care } \\
\text { professionals and care } \\
\text { home staff }\end{array}$ \\
\hline $\begin{array}{l}\text { Knight, } \\
2007\end{array}$ & $\begin{array}{l}\text { Collaborative } \\
\text { working using } \\
\text { integrated care } \\
\text { pathways }\end{array}$ & $\sqrt{ }$ & $\begin{array}{l}\text { Duration of intervention } \\
\text { only } \\
3 \text { years }\end{array}$ & $\sqrt{ }$ & $\begin{array}{l}\text { Duration of intervention } \\
\text { only }\end{array}$ & $\begin{array}{l}\text { Micro } \\
\text { Close collaboration } \\
\text { between health care } \\
\text { professionals and care } \\
\text { home staff }\end{array}$ \\
\hline $\begin{array}{l}\text { Mathews, } \\
2006\end{array}$ & $\begin{array}{l}\text { Collaborative } \\
\text { working using } \\
\text { integrated care } \\
\text { pathways }\end{array}$ & $\sqrt{ }$ & $\begin{array}{l}\text { Duration of intervention } \\
\text { only } \\
\text { No information }\end{array}$ & $\sqrt{ }$ & $\begin{array}{l}\text { Duration of intervention } \\
3 \text { hours on palliative care }\end{array}$ & $\begin{array}{l}\text { Macro } \\
\text { Close collaboration } \\
\text { between health care } \\
\text { professionals and care } \\
\text { home staff } \\
\text { Care pathways } \\
\text { NHS funded bed }\end{array}$ \\
\hline $\begin{array}{l}\text { Doherty, } \\
2008\end{array}$ & $\begin{array}{l}\text { Care home } \\
\text { support team }\end{array}$ & $\sqrt{ }$ & $\begin{array}{l}\text { Ongoing } \\
1 \text { year }\end{array}$ & $\sqrt{ }$ & $\begin{array}{l}\text { Ongoing } \\
\text { No details }\end{array}$ & $\begin{array}{l}\text { Meso } \\
\text { Dedicated care home } \\
\text { support team } \\
\text { established by NHS }\end{array}$ \\
\hline $\begin{array}{l}\text { Hasson, } \\
2008\end{array}$ & $\begin{array}{l}\text { Link nurses in } \\
\text { care homes }\end{array}$ & $\sqrt{ }$ & $\begin{array}{l}\text { Duration of intervention, } \\
\text { monthly meetings over } \\
3 \text { years }\end{array}$ & $\sqrt{ }$ & $\begin{array}{l}\text { Duration of intervention } \\
\text { only-nine } 3 \text { hour training } \\
\text { sessions }\end{array}$ & $\begin{array}{l}\text { Micro } \\
\text { Close collaboration } \\
\text { between health care } \\
\text { professionals and care } \\
\text { home staff }\end{array}$ \\
\hline Avis, 1999 & $\begin{array}{l}\text { District nurses } \\
\text { supporting care } \\
\text { home staff }\end{array}$ & $\sqrt{ }$ & $\begin{array}{l}\text { Duration of intervention } \\
\text { only } \\
2.5 \text { years }\end{array}$ & $\sqrt{ }$ & $\begin{array}{l}\text { Duration of intervention } \\
\text { Only. At least } 6 \text { training sessions } \\
\text { no details on length }\end{array}$ & $\begin{array}{l}\text { Micro } \\
\text { Close collaboration } \\
\text { between health care } \\
\text { professionals and care } \\
\text { home staff }\end{array}$ \\
\hline $\begin{array}{l}\text { Hockley, } \\
2005\end{array}$ & $\begin{array}{l}\text { Champions } \\
\text { identified in care } \\
\text { homes }\end{array}$ & $\sqrt{ }$ & $\begin{array}{l}\text { Duration of intervention } \\
\text { Only } \\
1 \text { year. Regular clinical } \\
\text { support no information } \\
\text { on frequency }\end{array}$ & $\sqrt{ }$ & $\begin{array}{l}\text { Duration of intervention - } \\
\text { Monthly collaborative learning } \\
\text { and monthly action learning } \\
\text { sets }\end{array}$ & $\begin{array}{l}\text { Micro } \\
\text { Close collaboration } \\
\text { between health care } \\
\text { professionals and care } \\
\text { home staff }\end{array}$ \\
\hline
\end{tabular}

documentation itself can become a useful source of continuity in an environment where there is high staff turnover and shift working in both sectors (Goodman, $\mathrm{C}$ et al: Can clinical benchmarking improve bowel care in care homes for older people? Final report submitted to the DoH Nursing Quality Research Initiative PRP, Centre for Research in Primary and Community Care, University of Hertfordshire, 2007).

\section{Limitations of existing evidence}

Given the limited number of studies in the review, their heterogeneity, poor quality, small size, and low level of detail, the scope for discussion of integrated working between care homes and primary health care professionals is limited and firm conclusions cannot be reached. Only five studies were conducted in residential care homes which reinforced previous findings that the majority of research is carried out in nursing homes, even though this is not where most older people in long term care live [14]. The absence of older people's views and resident centred outcomes from the studies was notable.
Moreover the majority of studies were only integrated at the micro level that is, close collaboration between care home staff and professionals, so little information was available on the impact of integration at meso and macro levels. There was wide variation amongst the studies in terms of their level of care home staff support and training, and the involvement of older people. Care home staff training and support ranged between those studies where it was ongoing and those where it was provided only on one occasion. Where there was support and training of care home staff it was not clear if the ultimate aim was to train staff to a level of expertise so that health services could withdraw.

\section{Implications for research}

There is a need for more research that addresses how integrated working can best be achieved and that evaluates the effect of integrated working on the health and wellbeing of older people, service use and cost. Research with care homes should reflect the context and constraints of working across public and independent services, and involve 
Table 9 Barriers to integrated working

\begin{tabular}{lc}
\hline & Barriers to integrated working \\
\hline 1. & Difficulty of NHS staff gaining the trust of care homes and NHS cynicism of care home expertise \\
\hline 3. & Lack of access to NHS services \\
\hline 4. & High staff turnover and lack of access to training \\
\hline 5. & Lack of staff knowledge and confidence \\
\hline 6. & Care homes were professionally isolated \\
\hline
\end{tabular}

care homes in the planning and design of interventions. Moreover as this population is known to have multiple co-morbidities that are often compounded by cognitive impairment there is a need for more studies to look at improving the quality of care for the care home population as a whole. Future evaluations should be large enough to detect a difference and outcomes need to be meaningful to care home staff and residents.

\section{Strengths and limitations of the review}

We used systematic and rigorous methods to synthesise the current evidence on integrated working between care homes and health care services and highlight areas for further research. There are, however, a number of methodological issues that could have a bearing on the validity of the results. Owing to a lack of evidence in this area we included all studies types including uncontrolled studies. Only four of our included studies were randomised controlled trials. Whilst uncontrolled studies might be more likely to be biased these broad inclusion criteria enabled us to investigate integrated working more widely and identify barriers and facilitators.

Although the studies reviewed were judged to have involved integrated working, it was not their main focus; only two studies referred to partnership working between care homes and health care services (Goodman, C et al: Can clinical benchmarking improve bowel care in care homes for older people? Final report submitted to the DoH Nursing Quality Research Initiative PRP, Centre for Research in Primary and Community Care, University of
Hertfordshire, 2007.)[44]. The information on integrated working was based on how the intervention was described, who was involved and at what level. It is possible that how this was reported in the studies reviewed did not capture the extent of the integration achieved.

\section{Conclusions}

Integrated working aims to ensure continuity of care, reduce duplication and fragmentation of services and places the patient as the focus for service delivery. This review identified a limited number of studies where the intervention supported integrated working between care homes and primary health care professionals. The narrow focus and single issue orientation of the majority of the studies did not engage with the needs of care home population or the context and organisation of their care. Outcome measures reflected the priorities of health care professionals rather than residents and care home staff. In view of the growing demand for residential and nursing home care together with funding constraints, more effective working between the NHS and care home providers is essential. There is an urgent need to develop and test interventions that promote integrated working and address the persistent divide between health services and independent providers.

\section{Funding}

This research was supported by the National Institute for Health Research Service Delivery and Organisation programme (project number 08/1809/231).

Table 10 Facilitators to integrated working

\begin{tabular}{|c|c|}
\hline & Facilitators to integrated working \\
\hline 1. & Care homes valued NHS input and training \\
\hline 2. & 'Bottom up' approach to train staff so that all levels of staff are involved \\
\hline 3. & Health care professionals acting as a advocate for care homes in relation to care \\
\hline 4. & Health care professionals acting as facilitators for sharing good practice and enabling care home staff to network \\
\hline 5. & Health care professionals promoting better access to services for the care home \\
\hline 6. & Care home managers supporting staff access to training for example, through establishing learning contracts. \\
\hline
\end{tabular}




\section{Disclaimer}

The views and opinions expressed therein are those of the authors and do not necessarily reflect those of the NIHR SDO programme or the Department of Health.

\author{
Author details \\ ${ }^{1}$ Centre for Research in Primary and Community Care, University of \\ Hertfordshire, Hatfield, AL10 9AB, UK. ${ }^{2}$ School of Health Sciences and Social \\ Care, Brunel University, Middlesex UB8 3PH, UK. ${ }^{3}$ Department of Primary Care \\ and Population Sciences, University College London, NW3 2PF, UK. \\ ${ }^{4}$ Department of Economics, University of Surrey, GU2 7XH, UK. Institute of \\ Health Research, Lancaster University, LA1 4YT, UK.
}

\section{Authors' contributions}

CG, FB, SI, KF designed the protocol, SD, FB, CG, CV, KF screened literature, reviewed papers for inclusion, extracted data and wrote the paper. All authors interpreted data, critically reviewed the paper and have approved the final manuscript.

\section{Competing interests}

All authors declare: no support from any organisation for the submitted work; no financial relationships with any organisations that might have an interest in the submitted work in the previous three years; no other relationships or activities that could appear to have influenced the submitted work.

Received: 26 May 2011 Accepted: 24 November 2011

Published: 24 November 2011

\section{References}

1. Department of Health: The Health Act, implemented in England and Wales in 2000. Department of Health; 1999.

2. Department of Health: The Commissioning Framework for Health and Well-being. Department of Health; 2007.

3. Laing and Buisson: Care of elderly people UK market survey 2009. London; 2009.

4. Care Quality Commission: The quality and capacity of adult social care services: an overview of the adult social care market in England 2008/ 2009. 2009.

5. Jacobs S, Alborz A, Glendinning C, Hann M: Health services for homes. A survey of access to NHS services in nursing and residential homes for older people in England. NPCRDC, University of Manchester; 2001.

6. Glendinning C, Jacobs S, Alborz A, Hann M: A survey of access to medical services in nursing and residential homes in England. British Journal of General Practice 2002, 52(480):545-549.

7. Goodman C, Woolley R, Knight D: District nurses' experiences of providing care in residential care home settings. Journal of Clinical Nursing 2003, 12:67-76.

8. Goodman C, Robb N, Drennnan V, Woolley R: Partnership working by default district nurses and care home staff providing care for older people. Health Soc Care Community 2005, 13(6):553-62.

9. Alzheimer's Society: Home from home: quality of care for people with dementia living in care homes. Alzheimer's Society London; 2007.

10. Department of Health: Dignity in Care: Practice Guide. Department of Health; 2007.

11. Department of Health: End of Life care strategy - promoting high quality care for all adults at the end of life. London. DoH; 2008.

12. Owen, et al: Better partnership between care homes and the NHS: findings from the My Home Life programme. Journal of Care Services Management 2008, 3(1):96-106.

13. Goodman C, Woolley R: Older people in care homes and the primary care nursing contribution: a review of relevant research. Primary Health Care Research and Development 2004, 5:179-187.

14. Joseph Rowntree Foundation: Providing nursing support within residential care homes. 2008, JRF ISSN 0958-3084. (Summary based on research from two interim reports. Wild D et al. The In-reach model described from the perspectives of stakeholders, home managers, care staff and the In-reach team. (May2007) University of West of England).
15. Kavanagh and Knapp: The impact on general practitioners of the changing balance of care for elderly people living in institutions. British Medical Journal 1998, 317(7154):322-7.

16. Royal College of Physicians, Royal College of Nursing and British Geriatrics Society: The health and care of older people in care homes - a comprehensive interdisciplinary approach. London: Royal College of Physicians of London; 2001.

17. Kayser Jones J, Schell E, Lyons W, et al: Factors that influence end-of-life care in care homes: the physical environment, inadequate staffing, and lack of supervision. Gerontologist 2003, , 2: 76-84.

18. Mozeley C, Sutcliffe C, Bagley H, et al: Towards Quality Care: outcomes for older people in care homes. PSSRU Ashgate, Aldershot; 2004.

19. Perry M, Carpenter I, Challis D, Hope K: Understanding the roles of registered general nurses and care assistants in care homes. Journal of Advanced Nursing 2004, 42(5):497-505.

20. Ham C: 'The ten characteristics of the high-performing chronic care system'. Health Economics, Policy and Law 2010, 5:71-90.

21. Kings Fund: How to deliver high-quality, patient-centred, cost-effective care Consensus solutions from the voluntary sector. London Kings Fund; 2010.

22. Rosen R, Ham C: Integrated Care: Lessons from Evidence and Experience. The Nuffield Trust for Research and Policy Studies in Health Services; 2008.

23. Kodner DL, Spreeuwenberg C: Integrated care: meaning, logic, applications, and implications - a discussion paper. International journal of integrated care 2002, 2(1):1-6.

24. Bond J, Gregson BA, Atkinson A: Measurement of Outcomes within a Multicentred Randomized Controlled Trial in the Evaluation of the Experimental NHS Nursing Homes. Age and Ageing 1989, 18:292-302.

25. British Geriatrics Society: The Teaching Care Home - an option for professional training. Proceedings of a Joint BGS and RSAS AgeCare Conference held in February 19991999 [http://www.bgs.org.uk/PDF\% 20Downloads/teaching_care_homes.pdf], accessed 080311.

26. Higgins JPT, Green S, editors: Cochrane Handbook for Systematic Reviews of Interventions 5.0.0., [updated February 2008].

27. Spencer L, Ritchie J, Lewis J, Dillon L: Quality in Qualitative Evaluation: A Framework for Assessing Research Evidence. Government Chief Social Researcher's Office: London; 2003.

28. Spencer, Richie: Qualitative data analysis for applied policy research. In Analysing qualitative data. Edited by: Bryman A, Burgess RG. London and New York Routledge; 1994:172-194.

29. Avis M, Greening Jackson J, Cox K, Miskella C: Evaluation of a project providing palliative care support to nursing homes. Health and Social Care in the Community 1999, 7(1):32-38.

30. Hockley J, Dewar B, Watson J: Promoting end-of-life care in nursing homes using an 'integrated care pathway for the last days of life'. Journal of Research in Nursing 2005, 10(2):135-152.

31. Mathews M, Finch J: Using the Liverpool Care Pathway in a nursing home. Nursing Times 2006, 102(37):34-35.

32. Knight $\mathrm{G}$, Jordan C: All-Wales integrated care pathway project for care homes: completing the audit cycle - retrospective baseline audit findings of documented care during the last days of life of residents who died in care homes and the re-audit findings following implementation of the ICP. Journal of integrated care pathways 2007, 11:112-119.

33. Hasson F, Kernohan G, Waldron M, Whittaker E, McLaughlin D: The palliative care link nurse role in nursing homes: barriers and facilitators. Journal of Advanced Nursing 2008, 233-242.

34. Vu T, Harris A, Duncan G, Sussman G: Cost-effectiveness of multidisciplinary wound care in nursing homes: a pseudo-randomized pragmatic cluster trial. Family Practice Advanced Access 2007, 372-379.

35. Opie J, Doyle C, Connor DW: Challenging behaviours in nursing home residents with dementia: a randomized controlled trial of multidisciplinary interventions. International Journal of Geriatric Psychiatry 2002, 17:6-13.

36. Llewellyn-Jones RH, Baikie KA, Smithers H, Cohen J, Snowdon J, Tennant CC: Multifaceted shared care intervention for late life depression in residential care: randomised controlled trial. British Medical Journal 1999, 319:676-82.

37. Proctor R, Stratton Powel H, Burns A, Tarrier N, Reeves D, Emerson E, Hatton C: An observational study to evaluate the impact of a specialist 
outreach team on the quality of care in nursing and residential homes. Aging and Mental Health 1998, 2(3):232-238.

38. Schmidt I, Claesson CB, Westerholm B, Nilsson LG, Svarstad BL: The impact of Regular Multidisciplinary Team Interventions on Psychotropic Prescribing in Swedish Nursing Homes. Journal of the American Geriatrics Society 1998, 46:77-82.

39. Crotty M, Halbert J, Rowett D, Giles L, Birks R, Williams H, Whitehead C: An outreach geriatric medication advisory service in residential aged care: a randomised controlled trial of case conferencing. Age and Ageing 2004, 33:612-617.

40. King M, Roberts MS: Multidisciplinary case conference reviews: improving outcomes for nursing home residents, carers and health professionals. Pharmacy World and Science 2001, 23:41-4.

41. Szczepura A, Nelson S, Wild D: In-reach specialist nursing teams for residential care homes: uptake of services, impact on care provision and cost-effectiveness. BMC Health Services Research 2008, 8:269.

42. Doherty $D$, et al: Examining the impact of a specialist care homes support team. Nursing Standard 2008, 23(5):35-41.

43. Joseph A, Boult C: Managed Primary Care of Nursing Home Residents. Journal of the American Geriatric Society 1998, 46:1152-1156.

44. Kane RL, Flood S, Bershadsky B, Keckhafer G: Effect of an Innovative Medicare Managed Care Program on the Quality of Care for Nursing Home Residents. The Gerontological Society of America 2004, 44(1):95-103.

\section{Pre-publication history}

The pre-publication history for this paper can be accessed here: http://www.biomedcentral.com/1472-6963/11/320/prepub

doi:10.1186/1472-6963-11-320

Cite this article as: Davies et al: A systematic review of integrated working between care homes and health care services. BMC Health Services Research 2011 11:320.

\section{Submit your next manuscript to BioMed Central and take full advantage of:}

- Convenient online submission

- Thorough peer review

- No space constraints or color figure charges

- Immediate publication on acceptance

- Inclusion in PubMed, CAS, Scopus and Google Scholar

- Research which is freely available for redistribution

Submit your manuscript at www.biomedcentral.com/submit 